\title{
Pore-water evolution and solute-transport mechanisms in Opalinus Clay at Mont Terri and Mont Russelin (Canton Jura, Switzerland)
}

\author{
Martin Mazurek ${ }^{1}$ (D) Antoine de Haller ${ }^{1,2}$
}

Received: 17 March 2016/ Accepted: 9 December 2016

(c) The Author(s) 2017. This article is published with open access at Springerlink.com

\begin{abstract}
Data pertinent to pore-water composition in Opalinus Clay in the Mont Terri and Mont Russelin anticlines have been collected over the last 20 years from longterm in situ pore-water sampling in dedicated boreholes, from laboratory analyses on drillcores and from the geochemical characteristics of vein infills. Together with independent knowledge on regional geology, an attempt is made here to constrain the geochemical evolution of the pore-waters. Following basin inversion and the establishement of continental conditions in the late Cretaceous, the Malm limestones acted as a fresh-water upper boundary leading to progressive out-diffusion of salinity from the originally marine pore-waters of the Jurassic low-permeability sequence. Model calculations suggest that at the end of the Palaeogene, pore-water salinity in Opalinus Clay was about half the original value. In the Chattian/Aquitanian, partial evaporation of sea-water occurred. It is postulated that brines diffused into the underlying sequence over a period of several Myr, resulting in an increase of salinity in Opalinus Clay to levels observed today. This hypothesis is further supported by the isotopic signatures of $\mathrm{SO}_{4}{ }^{2-}$ and ${ }^{87} \mathrm{Sr} /{ }^{86} \mathrm{Sr}$ in current pore-waters. These are not simple binary mixtures of sea and meteoric water, but their $\mathrm{Cl}^{-}$and
\end{abstract}

Editorial handling: P. Bossart and A. G. Milnes.

This is paper \#6 in the Mont Terri Special Issue of the Swiss Journal of Geosciences (see Bossart et al., 2017, Table 3 and Fig. 7).

Martin Mazurek

mazurek@geo.unibe.ch

1 Institute of Geological Sciences, University of Bern, Bern, Switzerland

2 Present Address: Earth and Environmental Sciences, University of Geneva, Geneva, Switzerland stable water-isotope signatures can be potentially explained by a component of partially evaporated sea-water. After the re-establishment of fresh-water conditions on the surface and the formation of the Jura Fold and Thrust Belt, erosion caused the activation of aquifers embedding the low-permeability sequence, leading to the curved profiles of various pore-water tracers that are observed today. Fluid flow triggered by deformation events during thrusting and folding of the anticlines occurred and is documented by infrequent vein infills in major fault structures. However, this flow was spatially focussed and of limited duration and so did not markedly affect the bulk pore-water.

Keywords Geochemical evolution · Pore-water tracers . Sea-water evaporation - Diffusion · Fluid flow · Veins . Nuclear waste disposal

\section{Introduction}

The Mont Terri rock laboratory is currently looking back on 20 years of research dedicated to the hydrogeological, geochemical and geomechanical characterisation of Opalinus Clay (Thury and Bossart 1999; Bossart and Thury 2007; Bossart et al. 2017). With regard to geochemical studies, a suite of novel techniques have been developed to characterise the chemical and isotopic compositions of pore-waters. This became necessary because the porespace architecture of Opalinus Clay is dominated by mean pore apertures in the range of nanometres, leading to extremely low hydraulic conductivity in the order of $1 \times 10^{-13} \mathrm{~m} / \mathrm{s}$ (Marschall et al. 2003; AF Consult 2012). Standard pore-water sampling techniques are generally not applicable to such low-permeability systems. Apart from other lines of evidence, this contribution is partially based 
Table 1 Major-ion and selected isotope data from water-sampling boreholes at Mont Terri and Mont Russelin

\begin{tabular}{|c|c|c|c|c|c|c|c|}
\hline Borehole & $\begin{array}{l}\text { Mont Terri } \\
\text { BWS-A1 }\end{array}$ & $\begin{array}{l}\text { Mont Terri } \\
\text { BWS-A2 }\end{array}$ & $\begin{array}{l}\text { Mont Terri } \\
\text { BWS-A3 }\end{array}$ & $\begin{array}{l}\text { Mont Terri } \\
\text { BWS-H2 }\end{array}$ & $\begin{array}{l}\text { Mont Terri } \\
\text { BPC-C }\end{array}$ & $\begin{array}{l}\text { Mont Terri } \\
\text { BBB3 }\end{array}$ & $\begin{array}{l}\text { Mont Russelin deep ground- } \\
\text { water (Staffelegg Fm.) }\end{array}$ \\
\hline Sampling date & 18.6 .97 & 18.6 .97 & 18.6.97 & 19.5 .09 & 31.8 .04 & 12.12 .11 & 1991 \\
\hline Laboratory & PSI & BGS & PSI/BGS & Hydroisotop & Andra & Hydroisotop & BGS \\
\hline $\mathrm{Na}^{+}(\mathrm{mg} / \mathrm{L})$ & 5610 & 4315 & 2864 & 4430 & 6414 & 4880 & \\
\hline $\mathrm{K}^{+}(\mathrm{mg} / \mathrm{L})$ & 65.3 & 130.0 & 40.6 & 51.8 & 69.6 & 59.5 & \\
\hline $\mathrm{Mg}^{2+}(\mathrm{mg} / \mathrm{L})$ & 344 & 311 & 151 & 286 & 542 & 370 & \\
\hline $\mathrm{Ca}^{2+}(\mathrm{mg} / \mathrm{L})$ & 570 & 43 & 283 & 455 & 774 & 547 & \\
\hline $\mathrm{Sr}^{2+}(\mathrm{mg} / \mathrm{L})$ & 35.5 & 2.2 & 31.6 & 40.1 & $42.9^{\mathrm{a}}$ & & \\
\hline $\mathrm{F}^{-}(\mathrm{mg} / \mathrm{L})$ & 0.77 & 0.17 & 0.47 & 0.8 & & & \\
\hline $\mathrm{Cl}^{-}(\mathrm{mg} / \mathrm{L})$ & 10,395 & 6067 & 4909 & 7420 & 11,628 & 8230 & 18,400 \\
\hline $\mathrm{Br}^{-}(\mathrm{mg} / \mathrm{L})$ & 36.3 & 23.9 & 15.2 & 27.1 & & 23.6 & 65 \\
\hline $\mathrm{SO}_{4}^{2-}(\mathrm{mg} / \mathrm{L})$ & 1251 & 1903 & 1082 & 1050 & 1651 & 1480 & \\
\hline $\begin{array}{l}\delta^{18} \mathrm{O}\left(\mathrm{H}_{2} \mathrm{O}\right) \\
\quad(\% \text { ov-smow })\end{array}$ & -8.49 & -8.70 & -9.17 & -9.18 & $-8.77^{\mathrm{b}}$ & -8.17 & -4.9 \\
\hline $\begin{array}{l}\delta^{2} \mathrm{H}\left(\mathrm{H}_{2} \mathrm{O}\right) \\
\quad(\% \text { ov-SMOw })\end{array}$ & -52.7 & -58.0 & -63.6 & -62.2 & $-47.9^{\mathrm{b}}$ & -57.4 & -28 \\
\hline $\begin{array}{c}\delta^{34} \mathrm{~S}\left(\mathrm{SO}_{4}{ }^{2-}\right) \\
(\% 0 \mathrm{~V}-\mathrm{CDT})\end{array}$ & 21.88 & & 21.01 & 22.5 & $21.3^{\mathrm{a}}$ & & \\
\hline $\begin{array}{c}\delta^{18} \mathrm{O}\left(\mathrm{SO}_{4}{ }^{2-}\right) \\
\left(\%{ }_{0 \mathrm{~V}-\mathrm{CDT}}\right)\end{array}$ & 11.97 & & 12.28 & 11.9 & & & \\
\hline${ }^{87} \mathrm{Sr} /{ }^{86} \mathrm{Sr}$ & 0.707651 & 0.707774 & 0.707715 & & & & \\
\hline References & $\begin{array}{l}\text { Pearson } \\
\text { et al. } \\
\text { (2003) }\end{array}$ & $\begin{array}{l}\text { Pearson } \\
\text { et al. } \\
\text { (2003) }\end{array}$ & $\begin{array}{l}\text { Pearson } \\
\text { et al. } \\
\text { (2003) }\end{array}$ & $\begin{array}{l}\text { Müller and } \\
\text { Leupin } \\
\text { (2012) }\end{array}$ & $\begin{array}{l}\text { Vinsot et al. } \\
\text { (2008) }\end{array}$ & Vogt (2013) & $\begin{array}{l}\text { Bureau Technique Norbert } \\
\text { (1993) }\end{array}$ \\
\hline
\end{tabular}

Data refer to the first sampling campaign that yielded sufficient water for analysis

a Sampled 8.10.05

b Sampled 5.1.05

on published data collected in the frame of several projects conducted at Mont Terri, including WS, WS-H, WS-I (Ground- and pore-water sampling), PC (Pore-water chemistry), HT (Hydrogen transfer), SF (Self-sealing of faults) and NT (Natural tracers).

Pore-waters at Mont Terri were recognised as geochemical archives of palaeo-fluids and of the mechanisms by which they interacted with the embedding aquifers. The obtained data were used to constrain solute-transport processes in the low-permeability sequence and the evolution of pore-water since the formation of the Jura Fold and Thrust Belt (Pearson et al. 2003; Mazurek et al. 2011). Folding and thrusting occurred at about 9-4 Ma (Becker 2000). Further, the geochemical studies were extended beyond the Mont Terri rock laboratory, including data from the adjacent Mont Russelin tunnel profile (Koroleva et al. 2011).

Pore-waters were collected in situ by long-term sampling in dedicated short boreholes. These experiments yielded the most complete chemical and isotopic characterisation, but given the limited number of sampling locations, the spatial resolution was limited. These data were augmented by various laboratory methods on drillcore samples, such as aqueous extraction, out-diffusion, squeezing, vacuum distillation and diffusive isotope exchange via the vapour phase. A large data set with good spatial resolution was obtained from these analyses. However, each laboratory method only yielded partial information on pore-water composition, and the representativity of the measurements for in situ conditions was an issue in some cases. Further information pertinent to porewater evolution was obtained from the isotopic signatures of calcite and celestite occurring in veins that were formed during Jura thrusting (De Haller et al. 2014). These veinsin most cases thin veinlets-record the isotopic composition of water that migrated along fractures at that time. The sampling areas in the Mont Terri and Mont Russelin tunnels are indicated in the geological profiles shown in Fig. 1.

It has long been recognised that pore-waters at Mont Terri and Mont Russelin cannot be explained as simple binary mixtures of sea and meteoric water (see Pearson et al. 2003 and Sect. 5.2 below). The objective of this contribution is to integrate the chemical and isotopic information archived in 
Fig. 1 Profiles across the Mont Terri and Mont Russelin anticlines, adapted from Freivogel and Huggenberger (2003) and Bureau Technique Norbert (1993). Blue bars in tunnels indicate sampled areas. Inset illustrates the concept of orthogonal distance (in metres) used to represent the spatial distribution of pore-water compositions
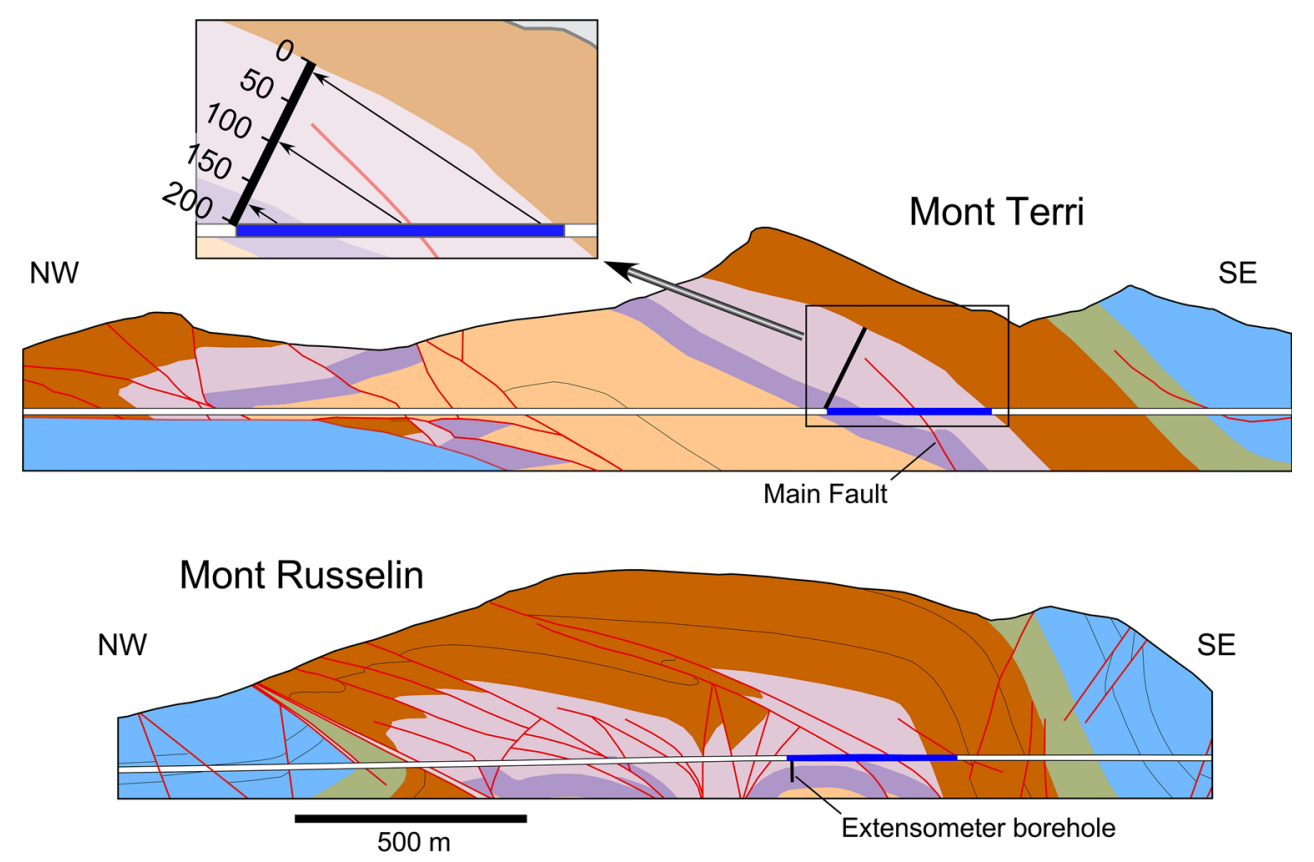

Upper Jurassic (Malm) - Limestones

Upper Jurassic (Malm) - Marls Bärschwil Formation

Middle Jurassic (Dogger) - Limestones

Passwang Formation at base

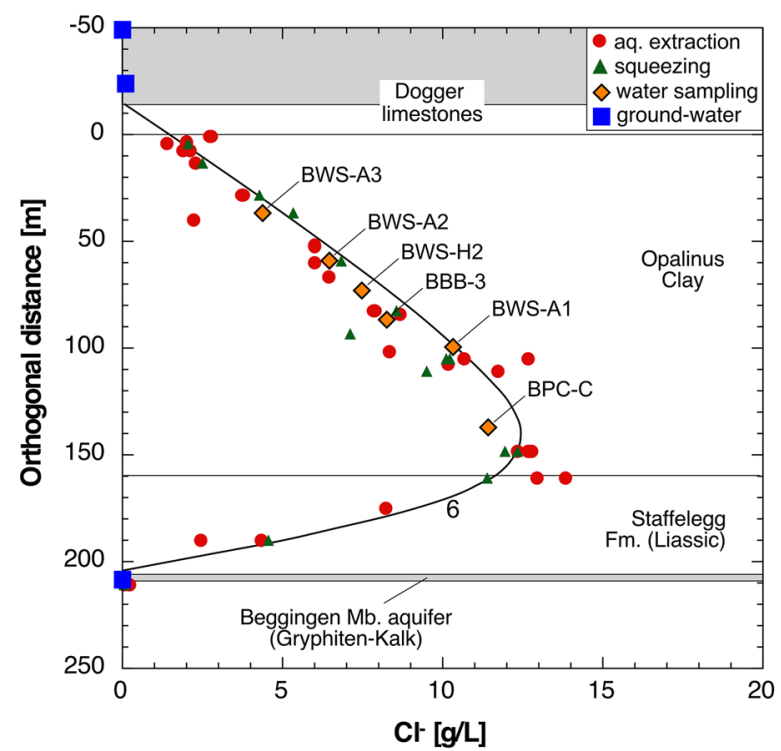

Fig. 2 Spatial distribution of $\mathrm{Cl}^{-}$in pore-waters from Mont Terri and Mont Russelin. "Orthogonal distance" refers to distance from the top of Opalinus Clay in the direction normal to bedding. Numbers indicate total diffusion times in Myr. Data from Pearson et al. (2003)

pore-waters and in vein infills, together with independent information on the regional geological evolution, in order to constrain fluid provenance and the long-term geochemical evolution at Mont Terri prior to Jura thrusting. Pore-water

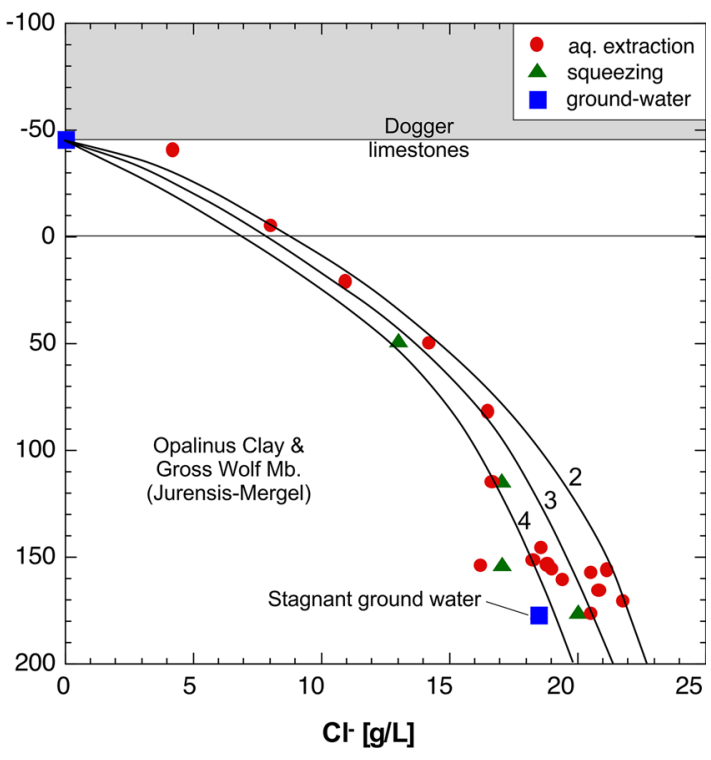

and Koroleva et al. (2011), model fits from Mazurek et al. (2011) and Koroleva et al. (2011). References for water samples taken in situ see Table 1. Aquifers are shown in grey

chemistry evolves over time in response to changing boundary conditions at the Earth's surface (e.g. marine vs. continental periods) and the possible impact of fluid-flow events related to tectonic activity. 


\section{Pore-water sampling techniques in the Mont Terri rock laboratory: methods and results}

\subsection{Laboratory methods}

A suite of methods were applied to quantify the chemical and isotopic composition of pore-waters at Mont Terri, including long-term sampling in dedicated boreholes, aqueous extraction, squeezing, diffusive exchange, vacuum distillation and out-diffusion (Rübel et al. 2002; Pearson et al. 2003). Most laboratory techniques applied on drillcores only yield partial data on pore-water composition, mostly pertinent to conservative constituents such as halogens $\left(\mathrm{Cl}^{-}, \mathrm{Br}^{-}\right)$, stable isotopes of water $\left(\delta^{18} \mathrm{O}, \delta^{2} \mathrm{H}\right)$ and dissolved noble gases $\left(\mathrm{He},{ }^{3} \mathrm{He} /{ }^{4} \mathrm{He}, \mathrm{Ar},{ }^{40} \mathrm{Ar} /{ }^{36} \mathrm{Ar}\right)$. At Mont Terri, a large number of drillcore samples were investigated over the entire clay-rich, low-permeability sequence, including the Opalinus Clay and the upper part of the Staffelegg Formation. This sequence is bounded by fractured limestone units at the top (Passwang Formation) and at the base (Beggingen Member of the Staffelegg Formation). These limestones have elevated permeabilities and constitute the hydrogeological boundaries of the clayrich sequence. Even though they do not represent economically productive water resources, ground-water flow is dominated by advection, and they are termed aquifers in the following. At Mont Russelin, a similar campaign was conducted in the southeastern limb of the anticline (Fig. 1; Koroleva et al. 2011). Figure 2 illustrates the systematic spatial variability of $\mathrm{Cl}^{-}$concentrations across both profiles, based on laboratory data and in situ sampling of pore and ground-waters. While sampling was made in short boreholes drilled from the tunnels, Fig. 2 represents the data as a function of orthogonal distance from the top of Opalinus Clay, i.e. data were projected to a plane perpendicular to stratification, as shown in the inset of Fig. 1. The orthogonal distance represents the minimum transport length for pore-water solutes to the bounding aquifer.

\subsection{In-situ sampling of pore-water}

The method of in situ sampling of pore-water in dedicated boreholes was first developed at Mont Terri in the frame of the WS experiment (Pearson et al. 2003). In contrast to most laboratory techniques, this approach potentially yields a complete data set on the major and trace element composition of the pore-water. Four boreholes were dry drilled with flushing by compressed air, and borehole sections at least $13 \mathrm{~m}$ away from the tunnel were isolated by single packers. The isolated intervals were filled with $\mathrm{N}_{2}$ and held at a pressure of $0.5-0.8$ bar over a total experimental period of about 4 years. Pore-water accumulated in the boreholes over time and was sampled recurrently. The total volumes of water collected were about 23, 6 and $18 \mathrm{~L}$ for boreholes A1, A2 and A3 (all drilled upward and perpendicular to bedding), while borehole A6 (drilled parallel to bedding) remained dry. Within each borehole, the flow rates also varied greatly over time between zero and a maximum of $65 \mathrm{~mL} / \mathrm{d}$. Similarly, the chemical compositions of the collected waters showed some limited variability, which may partly be linked to excavation activities in the vicinity of the water-sampling boreholes.

Compositions of waters obtained during the first sampling campaign, 6-15 months after installation, are given in Table 1 and shown in Fig. 2. The A1 water, originating from the central parts of Opalinus Clay (100 m orthogonal distance from the top of the formation), has the highest salinity, corresponding to slightly more than half that of sea-water. The A2 and A3 waters, originating from the upper part of Opalinus Clay (about 60 and $35 \mathrm{~m}$ orthogonal distance, respectively), show decreasing salinities. While the major-ion and most of the isotope data obtained in the water-sampling boreholes over 4 years are considered reliable, data pertinent to $\mathrm{pH}$ and dissolved inorganic carbon [and therefore $\mathrm{p}\left(\mathrm{CO}_{2}\right)$ ] remain problematic (Pearson et al. 2003). Given the fact that pore-water degassed into the $\mathrm{N}_{2}$-filled sampling interval, the carbonate system was perturbed.

A series of further experiments have been conducted in more recent times, shedding further light into pore-water chemistry. The setup of the PC and PC-C experiments included improvements to minimise disturbances, such as drilling with $\mathrm{N}_{2}$ rather than air. The concept of the PC experiment was diffusive equilibration between an artificial pore-water circulating in a borehole and the surrounding in situ pore-water. The goal of this experiment was to obtain better constraints on the carbonate system and $\mathrm{p}\left(\mathrm{CO}_{2}\right)$. However, it became evident during monitoring that the pore-water chemistry was disturbed by a leaking gel-electrode that triggered substantial microbial activity. This led, among others, to sulphate reduction and significant alteration of pore-water chemistry (Wersin et al. 2011). The concept of PC-C experiment was similar to that of the WS experiments but involved continuous flushing with argon in the test interval. The experiment yielded reliable and extensive analyses of seepage water after a transient phase (Vinsot et al. 2008). More recent experiments (WS-H and WS-I, Müller and Leupin 2012; Vogt 2013; Lorenz and Vogt 2014) were carried out to study inflow waters (wet spots), which were partly triggered by excavation activities. Chemical and isotopic analyses confirmed that these seepage waters correspond to local in situ waters because their compositions cannot be distinguished from those of the adjacent pore-waters. In particular, $\mathrm{Cl}^{-}$and $\mathrm{Br}^{-}$concentrations are consistent with the spatial distribution of these solutes as defined by Pearson 
et al. (2003). In the HT experiment, the effect of gaseous hydrogen injected into a borehole was analysed (Vinsot et al. 2014). Extensive sulphate reduction was observed, induced by microbial activity in the borehole. Selected data from these experiments are shown in Table 1.

\subsection{Stagnant ground-water at Mont Russelin}

In the Mont Russelin anticline, a ground-water in the Beggingen Member of the Staffelegg Formation underlying Opalinus Clay could be sampled in an extensometer borehole (location shown in Fig. 1), during tunnel construction (Bureau Technique Norbert 1993). Because of some degree of contamination originating from the cementitious backfill of the borehole, only halogen and water-isotope data are considered reliable and are reported in Table 1 . This water yielded among the highest salinities and the least negative $\delta$ values for water isotopes when compared to all other data from Mont Terri and Mont Russelin (Table 1, Fig. 2). This composition contrasts with that of the young and fresh water found in the same unit at Mont Terri. The difference is due to the fact that while erosion exhumed strata down to the Triassic at Mont Terri, leading to an active flow system, there was much less erosion at Mont Russelin, where the Staffelegg Formation does not crop out and is always covered by Opalinus Clay (as shown in the profiles in Fig. 1). The absence of in- and exfiltration areas and the protected position in the core of the anticline is taken as evidence that the ground-water of the Staffelegg Formation at Mont Russelin is a stagnant water body unaffected by processes postdating the thrusting and folding of the anticline but in diffusive equilibrium with the overlying clay-rich rocks. Therefore, Mazurek et al. (2011) and Koroleva et al. (2011) concluded that this water likely represents the composition of porewaters that resided in the low-permeability sequence at the time of Jura thrusting and related vein formation.

\section{Structural features and petrography of veins}

Veins at Mont Terri occur in structures that can be attributed to thrust-fault systems that developed during the formation of the anticline (Nussbaum et al. 2011, 2017). In spite of substantial brittle deformation, veins in Opalinus Clay are infrequent and thin, indicating that fluid flow across the formation during deformation was limited. They consist of calcite, celestite and subordinate pyrite. Frequently, they are hardly visible in outcrop but can be identified in thin section. Within the Main Fault (shown in Fig. 1), the largest thrust fault within the Mont Terri rock laboratory (Nussbaum et al. 2011, 2017), veins are typically $<1 \mathrm{~mm}$ thick and also occur within a few metres around the fault, documenting a diffuse pattern of deformation and vein precipitation.

In order to retrieve friable, cohesionless fault rock with as little mechanical disturbance as possible, a special drilling technique was used to minimise damage due to drilling. A steel device with guiding tubes was used to drill eight perforation holes ( $25 \mathrm{~mm}$ each) $60 \mathrm{~cm}$ into the Main Fault (Fig. 3a). The ring perforation was subsequently filled with epoxy resin. After polymerisation, the interval was overcored $(143 \mathrm{~mm})$, placed in an acrylic liner and further stabilised by filling the ring space with epoxy resin. A more detailed documentation of the drilling technique can be found in Nussbaum et al. (2006). Figure 3b shows a slice of the core obtained by this technique and provides a cross section across one of the major fault planes within

(a)

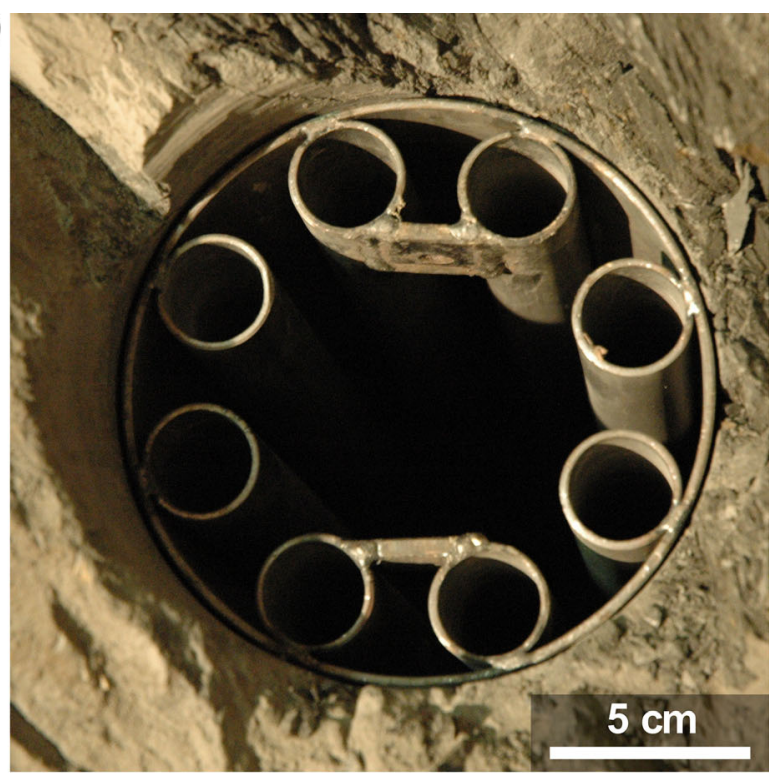

(b)

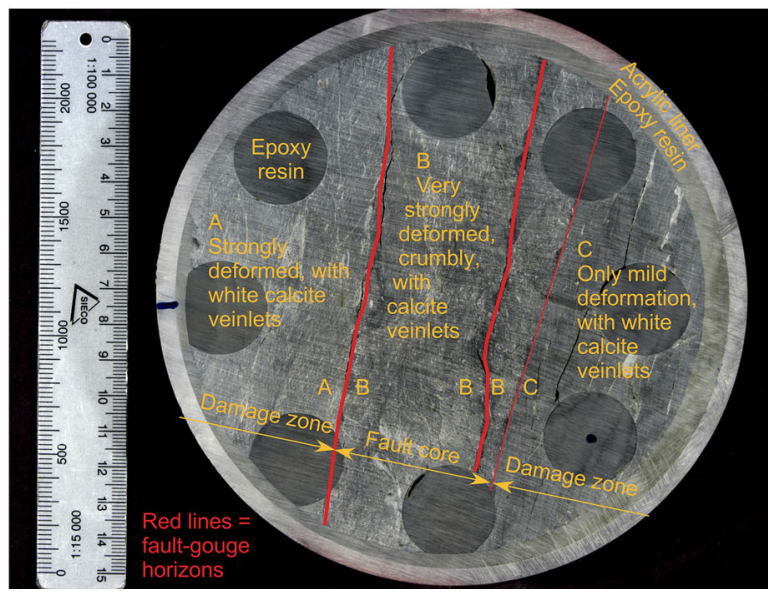

Fig. 3 Drilling procedure and structural features in retrieved core obtained from a borehole drilled into one of the main internal fault planes of the Main Fault at Mont Terri. Diameter of core is $14.3 \mathrm{~cm}$. a Device with 8 tubes used as guides to drill a ring perforation around the core. b Cross section of retrieved core showing the structural elements of the penetrated fault segment 
(a)

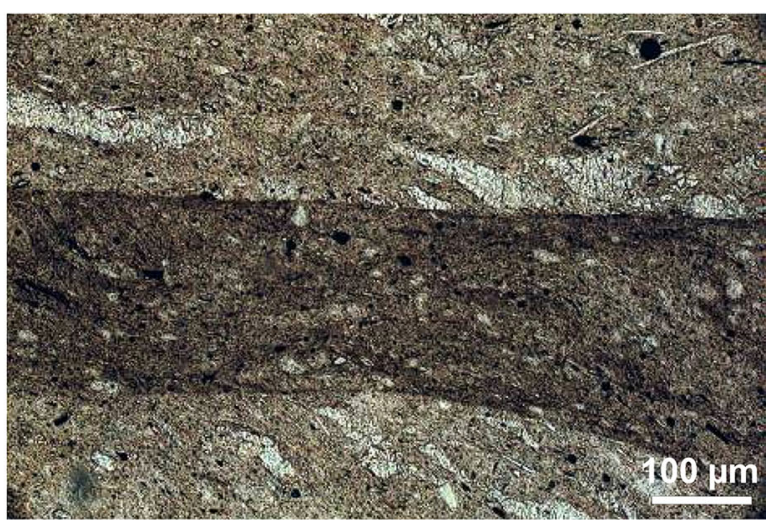

(b)

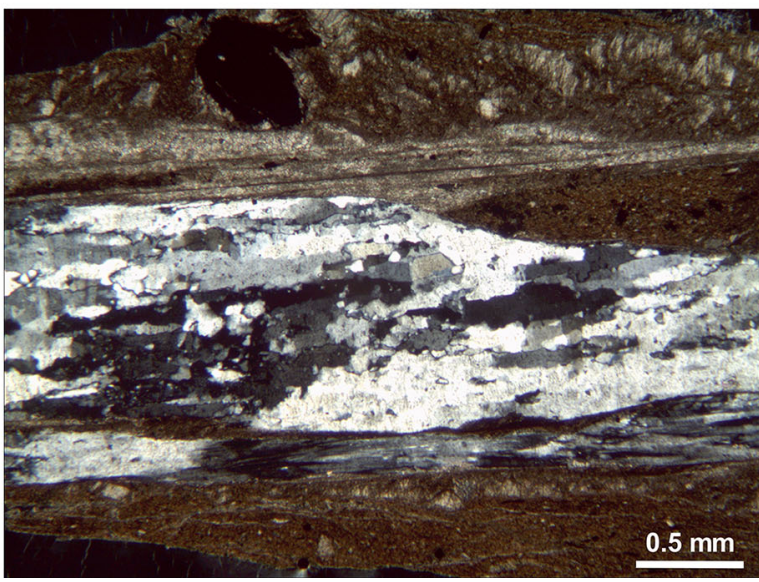

Fig. 4 Microscopic features of the Main Fault at Mont Terri. a Cohesionless fault-gouge horizon with sharp boundaries. Length of picture is $0.7 \mathrm{~mm}$, parallel polars. b Celestite-calcite vein with fibrous texture, indicating syntectonic growth. Length of picture is $3.5 \mathrm{~mm}$, crossed polars

the Main Fault. It consists of a fault core, which is bounded by mm-thick horizons of fault gouge (Fig. 4a), surrounded on both sides by a less strongly deformed damage zone. Veinlets are recognised mainly in the damage zone and less in the fault core (Fig. 3b). Microscopic investigations show that they are often fibrous, indicating syn-tectonic growth of both calcite and celestite (Fig. 4b). The youngest stage of vein formation occurred in microscopic pull-apart structures formed associated to the last shear movements. Outside the Main Fault, veinlets were separated by disaggregating the rock using the technique described in de Haller et al. (2014), followed by hand picking. Petrographically, these veins cannot be distinguished from those within the Main Fault.

\section{Isotopic composition of vein infills, whole rocks and current pore-water}

The sampling and analytical methods for pore-waters are documented in Pearson et al. (2003), those for isotopic measurements on minerals and rocks are described in de Haller et al. (2014).

\subsection{Oxygen and carbon isotopes in calcite}

As shown in Table 2 and Fig. $5, \delta^{18} \mathrm{O}$ of whole-rock carbonate varies in the range $23.4-29.1 \%{ }^{0}$-SMOw, largely consistent with values for marine calcite at the time of deposition (Gomez et al. 2009; Korte et al. 2015). Vein calcite has consistently lower $\delta^{18} \mathrm{O}$ values. Within the Main Fault, the average fractionation between whole-rock carbonate and vein calcite is $4.5 \%$ v-smow, suggesting that the veins precipitated at higher temperature and/or from waters with $\delta^{18} \mathrm{O}$ values lower than that of sea-water. Vein calcite from Mont Russelin has $\delta^{18} \mathrm{O}$ values of $17.1-17.4 \%{ }^{0}$ smow, which is lower than the values at Mont Terri (19.3-22.9\%ov-sMOW).

\subsection{Sulphur and oxygen isotopes in celestite and in current pore-water}

Celestite was observed exclusively in veins hosted by Opalinus Clay, and the sulphate-isotope data are given in Table 2 and Fig. 6. Data for whole-rock gypsum or anhydrite from the underlying Triassic evaporites (Gipskeuper, Muschelkalk) are also included (data from Table 3). The isotopic composition of sulphate in current pore-water was obtained by long-term sampling in boreholes distant from any major deformation features (data in Table 1, Pearson et al. 2003; Müller and Leupin 2012) and is also shown in Fig. 6. Only data from the first sampling in each borehole are shown, while later samplings (after about a year) diverge in different directions, most probably due to microbially mediated redox reactions in the sampling interval.

\section{$4.3{ }^{87} \mathrm{Sr} /{ }^{86} \mathrm{Sr}$ in calcite, celestite, whole-rock carbonate and in current pore-water}

Data for veins are shown in Table 2, and whole-rock data are given in Table 3. Further whole-rock carbonate data were obtained for the generally clay-rich units between the Passwang and Staffelegg Formations, including Opalinus Clay. However, $\mathrm{Sr}$ in acetic-acid leachates from such rocks may include significant contributions from clay minerals and possibly feldspars in addition to carbonate (see also Lerouge et al. 2010). Therefore, these data are not considered reliable and not reported here.

All data are shown in Fig. 7, together with data for current pore-water (Table 1; Pearson et al. 2003) and for $\mathrm{Sr}$ sorbed on clay minerals (from Lerouge et al. 2010). Vein calcite, vein celestite (including the two measurements from Mont Russelin) and current pore-water in Opalinus Clay occupy overlapping fields. The ${ }^{87} \mathrm{Sr} /{ }^{86} \mathrm{Sr}$ ratios in whole rocks from the Triassic as well as from the middle/ late Dogger are within or close to the respective fields of 


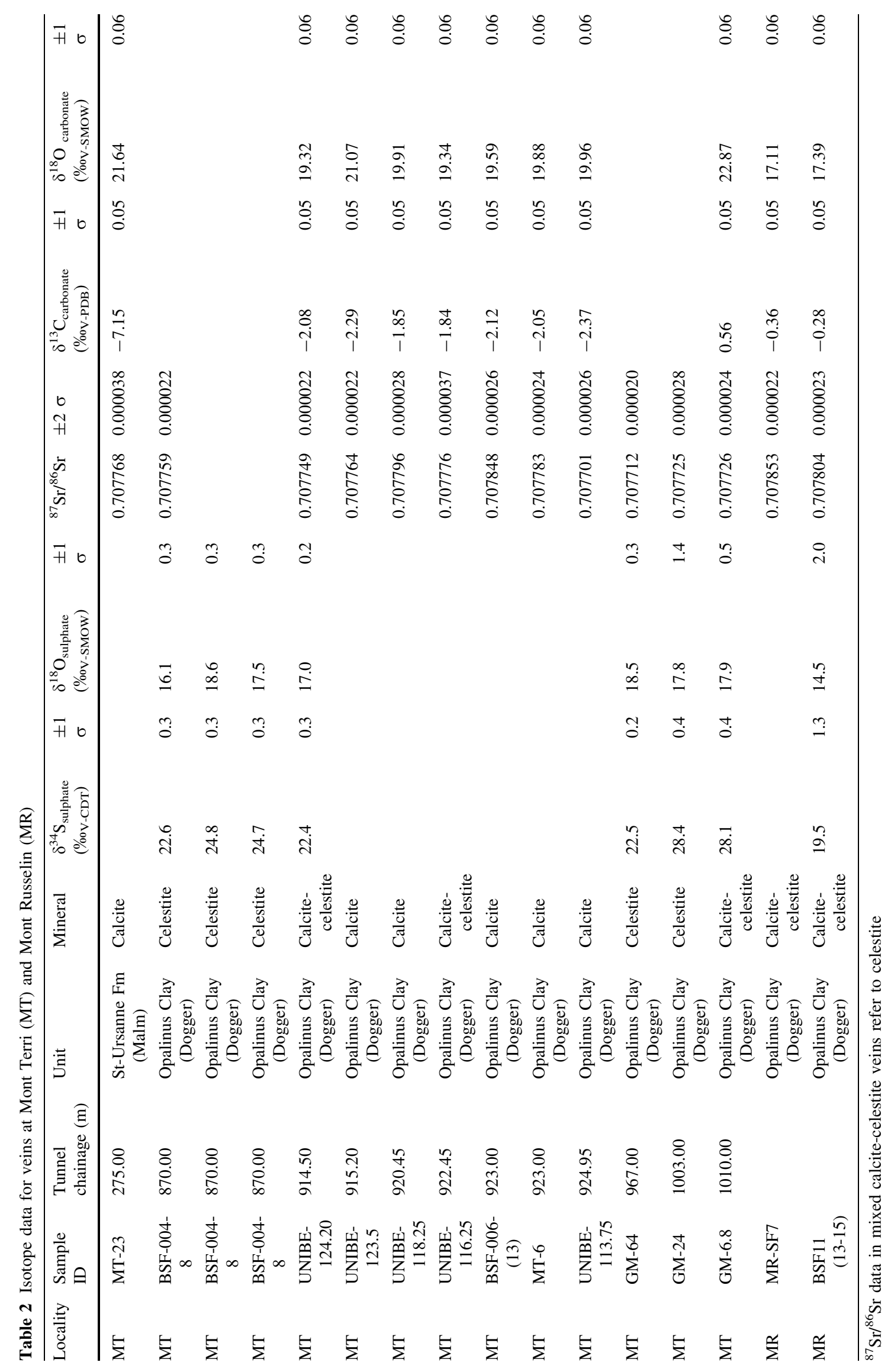




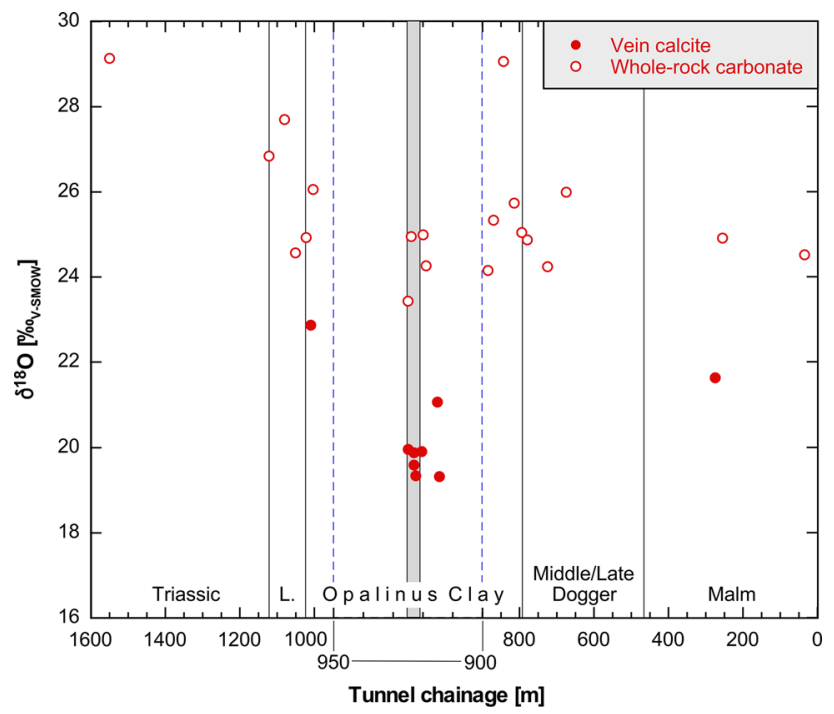

Fig. $5 \delta^{18} \mathrm{O}$ of vein calcite and whole-rock carbonate along the tunnel profile at Mont Terri. Note the expanded length scale in the region of the Main Fault (shown in grey). L. Liassic

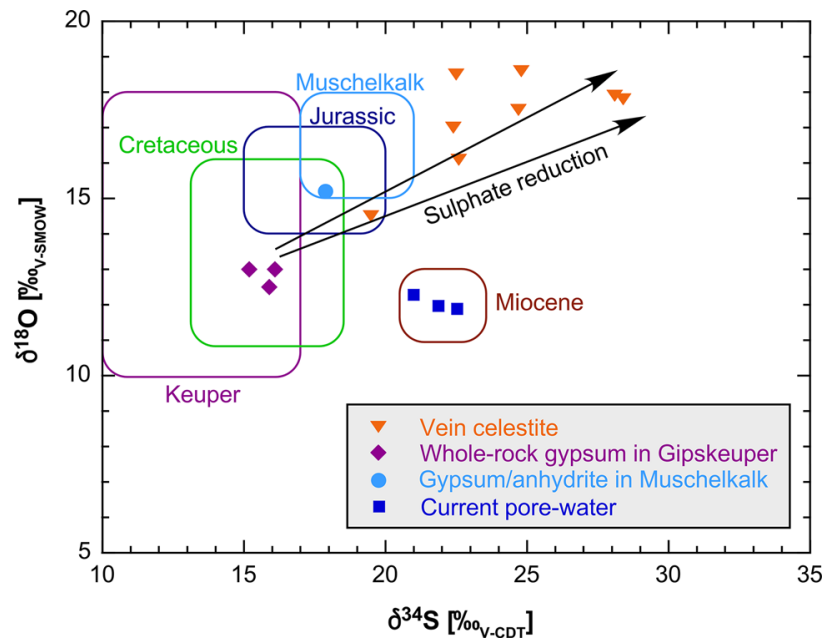

Fig. 6 Isotopic composition of sulphate in rocks, veins and porewaters at Mont Terri. Fields are shown for marine sulphate during different geological periods (based on Claypool et al. 1980 and Balderer et al. 1991). Data for current pore-waters are from Pearson et al. (2003) and Müller and Leupin (2012)

contemporary sea-water according to the compilation of McArthur et al. (2012). On the other hand, all vein data as well as current pore-water in Opalinus Clay yield ${ }^{87} \mathrm{Sr} /{ }^{86} \mathrm{Sr}$ ratios that are substantially higher than late Toarcian/ Aalenian sea-water according to McArthur et al. (2012), indicating an external component of $\mathrm{Sr}$ with a higher ${ }^{87} \mathrm{Sr} /{ }^{86} \mathrm{Sr}$ ratio. In principle, such a component can be derived either from the underlying Keuper, or from a Tertiary sea-water that may have infiltrated during the deposition of the Lower Freshwater Molasse (USM) or the Upper Marine Molasse (OMM).

\section{Discussion}

\subsection{Main characteristics of pore-waters}

Pore-water composition at Mont Terri and Mont Russelin is dominated by $\mathrm{Na}^{+}, \mathrm{Cl}^{-}$and $\mathrm{SO}_{4}{ }^{2-}$ (Table 1 ). The porewaters span a wide range of salinities $\left(\mathrm{Cl}^{-}\right.$concentration profiles are shown in Fig. 2). At Mont Terri, total dissolved solids (TDS) increase with the distance from the freshwater aquifer in the Passwang Formation and reach a maximum of $28 \mathrm{~g} / \mathrm{L}$ before returning sharply to low values towards the underlying fresh-water aquifer in the Beggingen Member (Staffelegg Formation). At Mont Russelin, the upper part of the profile looks similar to that at Mont Terri, but in the lower part salinity keeps increasing, reflecting the fact that the aquifer in the Staffelegg Formation is stagnant and contains an old, saline water, and reaching a TDS value of $41 \mathrm{~g} / \mathrm{L}$, slightly higher than modern seawater. Mazurek et al. (2011) and Koroleva et al. (2011) interpreted the regular distributions of $\mathrm{Cl}^{-}, \delta^{18} \mathrm{O}, \delta^{2} \mathrm{H}$ and dissolved $\mathrm{He}$ as a consequence of diffusive exchange between pore-waters and aquifers since the time these were first flushed by fresh water. The observed spatial distributions of all tracers could be explained as diffusion profiles with modelled evolution times that are plausible from a geological perspective, in particular $6 \mathrm{Myr}$ at Mont Terri and 2-4 Myr at Mont Russelin. (Note that in accordance with Aubry et al. (2009), Myr is used here to address duration, while Ma refers to absolute dates.)

The $\mathrm{Cl}^{-} / \mathrm{Br}^{-}$ratio of pore-waters both at Mont Terri and at Mont Russelin is consistently close to the current seawater ratio of $290 \mathrm{~g} / \mathrm{g}$, independent of the salinity of the water (Fig. 8). This is also true for the sample of deep, stagnant ground-water in the Beggingen Member (Staffelegg Formation) of the Mont Russelin anticline. It is therefore concluded that all pore-waters have a marine component.

\subsection{Provenance of pore-waters: evidence from the literature}

Based on pore-water chemistry alone (Fig. 2 and Fig. 8), the pore-waters could be explained as binary mixtures of sea-water and meteoric water, i.e. as products of the diffusive exchange with the embedding fresh-water aquifers since the time these were exhumed and activated. However, this hypothesis does not fit with the evidence from stable isotopes of water. Considering binary mixing of sea and temperate- to warm-climate meteoric water, the fraction of the meteoric component obtained from the stableisotope data is much higher when compared to that calculated from the $\mathrm{Cl}^{-}$concentration (Fig. 9). This is also 


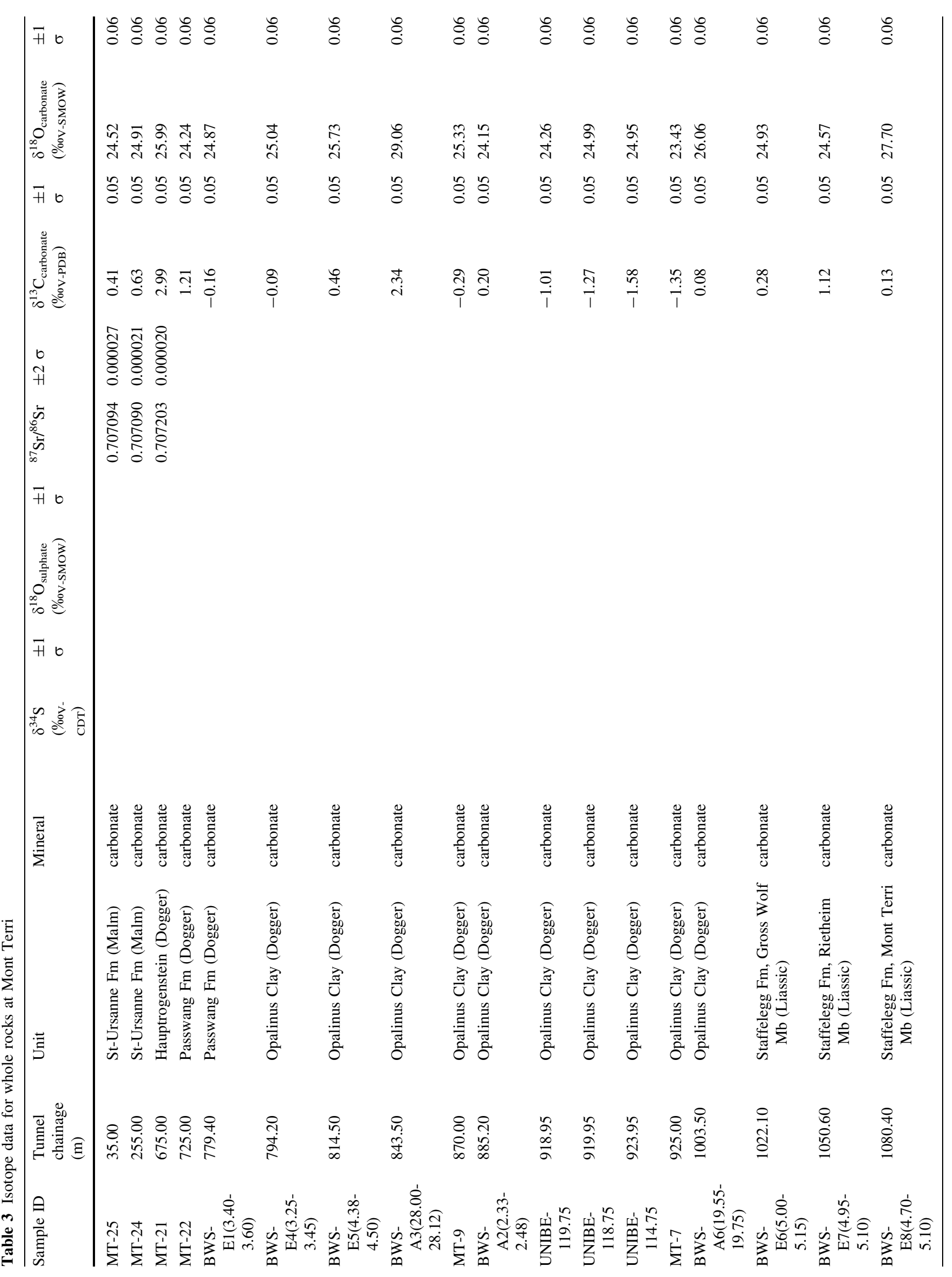




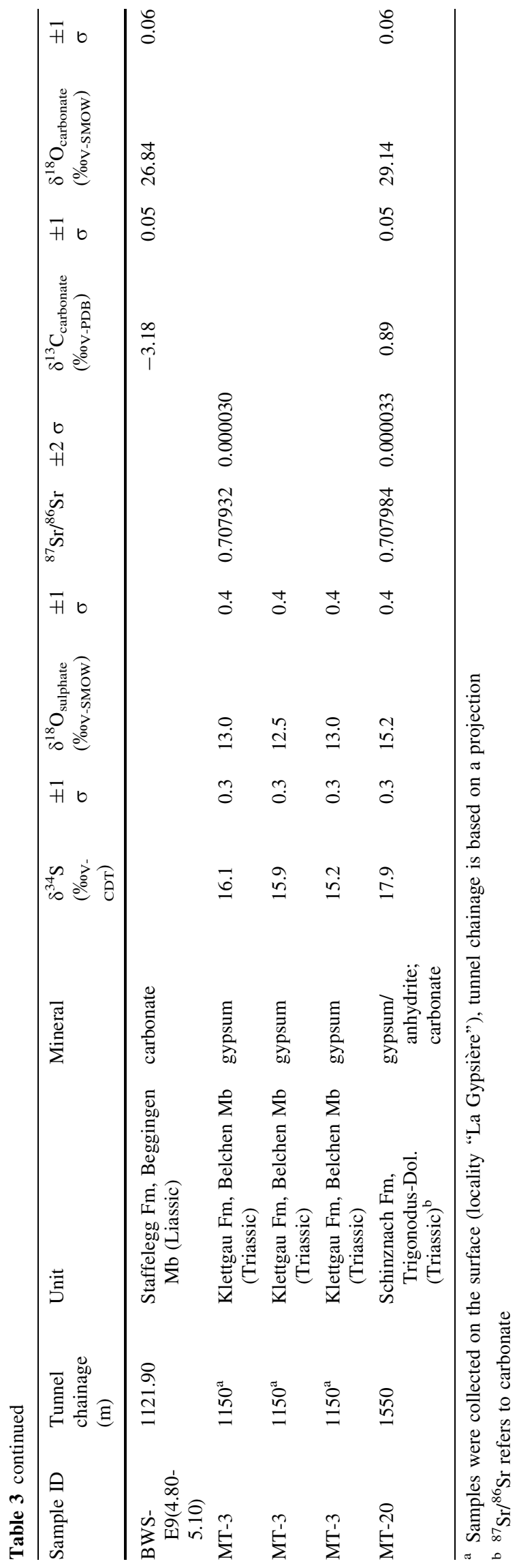

illustrated by the ground-water sample from Mont Russelin, with a near-marine $\mathrm{Cl}^{-}$concentration of $18.4 \mathrm{~g} / \mathrm{L}$ but markedly negative $\delta^{18} \mathrm{O}$ and $\delta^{2} \mathrm{H}$ values of -4.9 and $-28 \%$ o-smow, respectively.

The difficulty to explain the pore-waters at Mont Terri and Mont Russelin as mixtures of sea and meteoric water has already been discussed by Pearson et al. (2003). They considered interactions of pore-water with clay minerals, effects of ion filtration and differences in the diffusion coefficients for $\mathrm{Cl}^{-}$and water as potential mechanisms to rationalise the provenance of the waters. On a qualitative level, they discarded the former two mechanisms and proposed that the discrepant mixing proportions could be due to the higher diffusion coefficient for the water molecule when compared to that for halogens. However, Mazurek et al. (2011) performed model calculations and showed that differences in the diffusion coefficients are insufficient to explain the observations. These authors concluded that the $\delta^{18} \mathrm{O}$ and $\delta^{2} \mathrm{H}$ values of the pore-water must have been negative at the time when diffusive exchange was initiated after flushing of the embedding aquifers with fresh meteoric water. They consider the deep ground-water from Mont Russelin as a good proxy of the water present in the system prior to the formation of the Jura Fold and Thrust Belt, even though its origin cannot be explained in a simple way.

\subsection{Regional hydrogeological and hydrochemical evolution}

A potentially better understanding of the early part of porewater evolution can be obtained by considering current knowledge of palaeo-hydrogeology and hydrochemistry for times prior to the formation of the Jura Fold and Thrust Belt.

\subsubsection{Jurassic to Cretaceous (201-66 Ma; chronostratigraphy according to Cohen et al. 2013)}

Marine conditions prevailed in the area of interest during Jurassic and large parts of Cretaceous times, and sedimentation took place. It is therefore safe to say that porewaters in the sedimentary pile had a composition close to that of sea-water. In the late Cretaceous, the basin was inverted, leading to exhumation and erosion.

\subsubsection{Palaeogene (66-23 Ma)}

Due to predominantly continental conditions and therefore long-term exposure to meteoric waters in the Palaeogene, karst formation occurred in the limestones of the Malm, which became a regional aquifer. In the area of interest, Palaeogene karstification is not known in the underlying 


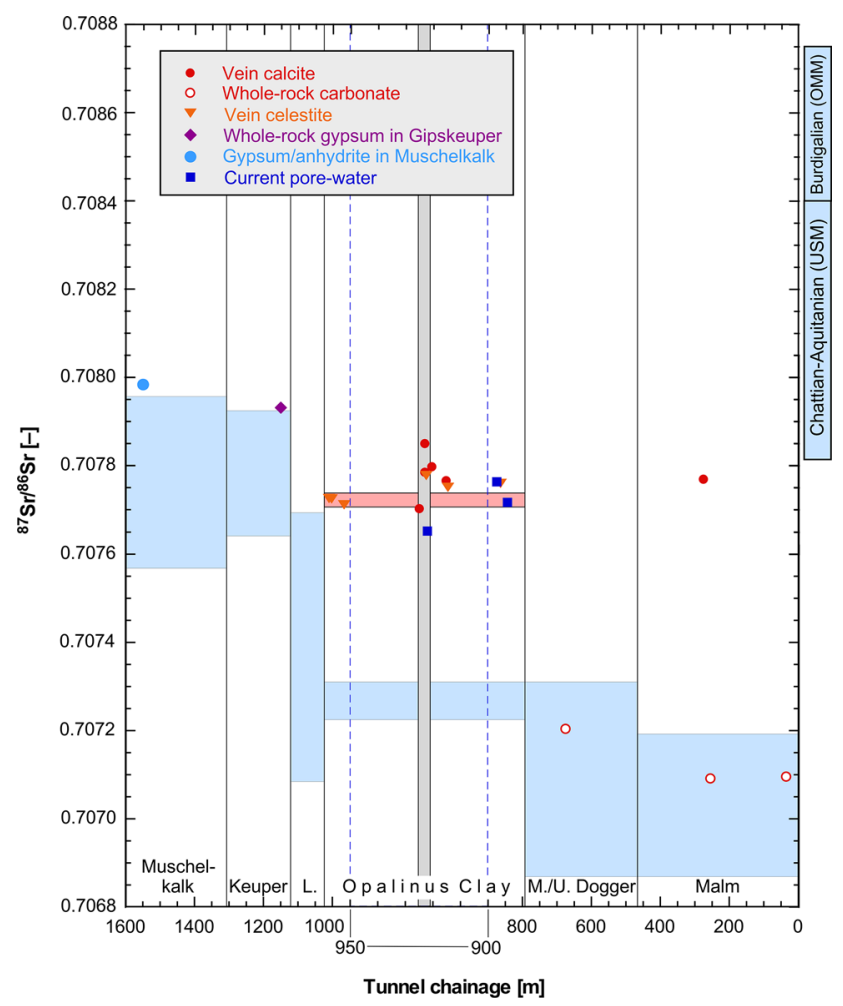

Fig. $7{ }^{87} \mathrm{Sr} /{ }^{86} \mathrm{Sr}$ ratios in vein minerals, whole-rock carbonate/sulphate and current pore-water at Mont Terri. Data for pore-water are from Pearson et al. (2003). Blue areas indicate ${ }^{87} \mathrm{Sr} /{ }^{86} \mathrm{Sr}$ values for contemporary sea-water according to McArthur et al. (2012). Pink bar shows range of ${ }^{87} \mathrm{Sr} /{ }^{86} \mathrm{Sr}$ for $\mathrm{Sr}$ sorbed on clay minerals in Opalinus Clay according to Lerouge et al. (2010). Grey bar indicates the Main Fault. Note the break in horizontal scale in the region of the Main Fault

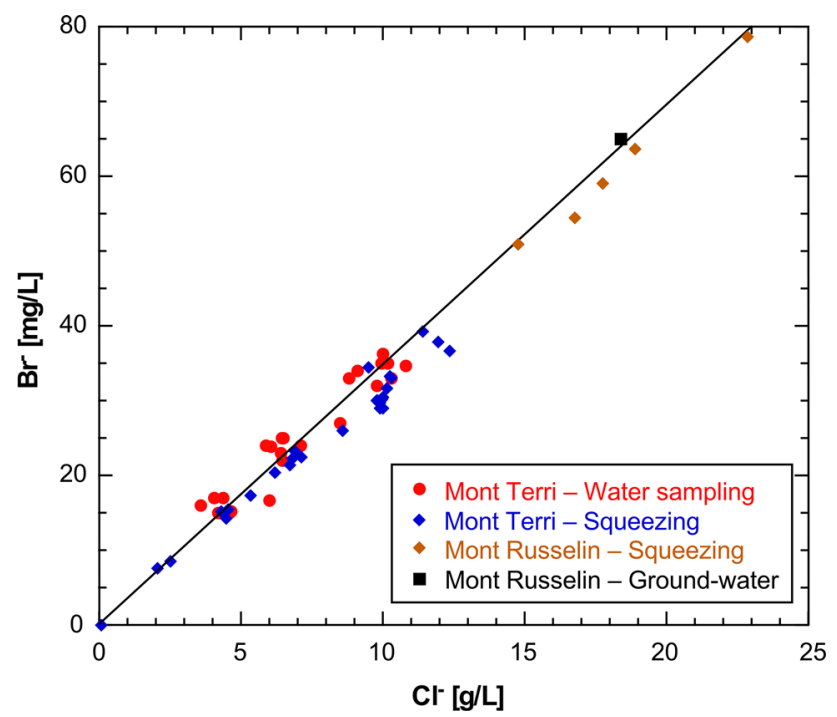

Fig. $8 \mathrm{Cl}^{-}$and $\mathrm{Br}^{-}$concentrations in pore-waters at Mont Terri and Mont Russelin. Data are from Pearson et al. (2003) and Koroleva et al. (2011). Solid line indicates the $\mathrm{Cl}^{-} / \mathrm{Br}^{-}$ratio in modern seawater

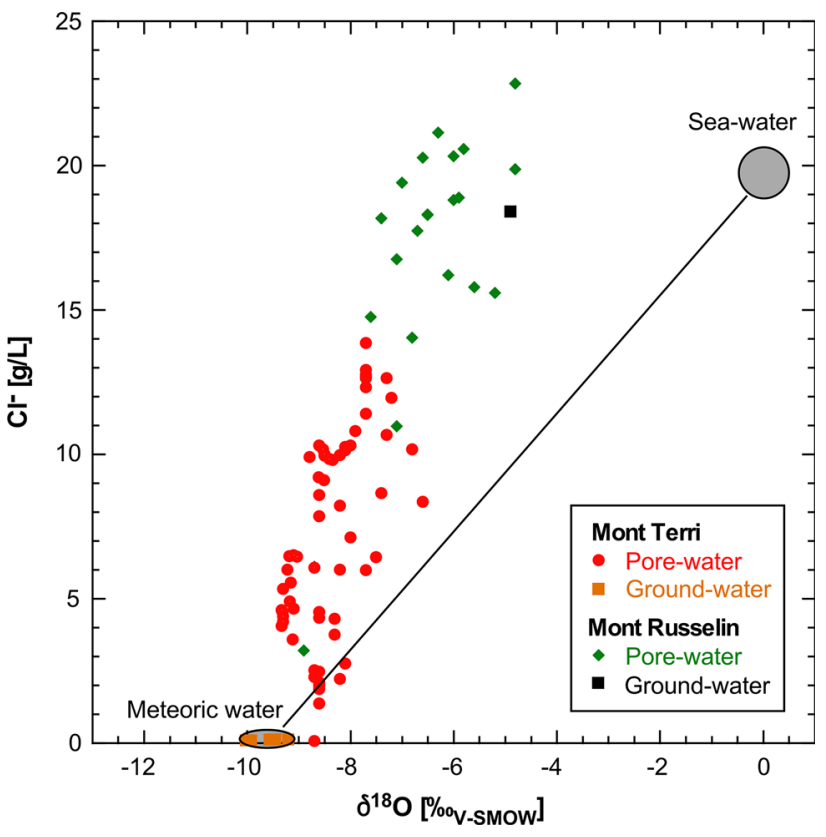

Fig. $9 \mathrm{Cl}^{-}$concentrations versus $\delta^{18} \mathrm{O}$ in pore and ground-waters. Mixing line between sea-water and current meteoric water at Mont Terri is also shown

limestone units, such as the Hauptrogenstein (P. Jordan, pers. comm. Dec. 2015). Therefore, conceptually, the Malm aquifer can be considered as a fresh-water boundary leading to progressive out-diffusion of salinity from the underlying, largely clay-rich sequence.

While $\mathrm{NaCl} / \mathrm{KCl}$ salts were deposited in the Rhine Graben during the Eocene, there is no evidence of marine environments at that time in the Mont Terri region (Pirkenseer et al. 2010). In the Oligocene, marine incursions of limited duration may have occurred from the Rhine Graben, even though the Mont Terri region was located along the southern shoreline (Picot et al. 2008; Pirkenseer et al. 2010, 2011, 2013). The possible presence of short brackish or marine stages does not change the fact that for most of the Palaeogene, the region was exposed to continental conditions.

\subsubsection{Aquitanian (23-20 Ma)}

In spite of the generally continental conditions in northern Switzerland (deposition of the Lower Freshwater Molasse (USM), 28-20.5 Ma), the region of the Folded Jura experienced marine episodes in the late Chattian and Aquitanian. Evaporites, mainly gypsiferous marls, were identified at several locations and interpreted as sabkha deposits (Kissling 1974; Mojon et al. 1985; Berger 1996; Weidmann et al. 2014). Kuhlemann and Kempf (2002) attribute these units to marine incursions from the northwest (Bresse-Rhône Graben, Rhine Graben). The potential 
effects of brines on the surface on the composition of porewaters in the underlying units are discussed below.

\subsubsection{Burdigalian (20-16 Ma)}

In the external parts of the Swiss Molasse Basin, the Burdigalian Upper Marine Molasse (OMM, 20.4-16 Ma) was deposited in a narrow channel between the Alpine front and the foreland bulge and records the last marine period (Kuhlemann and Kempf 2002). The extent of the OMM towards the northwest is not well known due to erosion in the Jura Mountains. In the early Burdigalian, the Mont Terri region was either continental with no sedimentation or marine deposits of this age were eroded (Berger 1996; Berger et al. 2005). In the late Burdigalian, the region was located close to the coast line, and the conditions were shallow marine to brackish (Berger et al. 2005; Becker and Berger 2004). Today, the nearest outcrops of the OMM are about $20 \mathrm{~km}$ to the southeast near Moutier (Pfirter et al. 1996). Thus, it is possible in principle but still remains unclear whether or not the Mont Terri area has been exposed to marine or brackish conditions over substantial time periods during the Burdigalian. There are no records of restricted environments in the OMM where sea-water evaporation may have played a major role. The Burdigalian OMM was the last marine stage in the region, and continental conditions have prevailed since then.

\subsection{Partial evaporation of sea-water: a potential mechanism to rationalise observed pore-water compositions}

Partial evaporation of sea-water apparently took place in the Aquitanian, meaning that the upper boundary condition for the low-permeability sequence changed drastically from meteoric to brine for some time. Sea-water evaporation is a process that results in distinct and non-linear effects on salinity and water-isotope composition. Below halite saturation, concentrations of halogens increase linearly with evaporation, while the evolution of water isotopes follows a more complex and non-linear scheme. The stable-isotope composition of evaporating sea-water depends on relative humidity (determining the relative contribution of kinetic effects of evaporation), on temperature (determining the fractionation factors) and ion concentrations (determining isotope fractionations between water in hydration shells of ions and free water). Laboratory experiments by Craig et al. (1963), Craig and Gordon (1965) and Gonfiantini $(1965,1986)$ indicate that $\delta^{18} \mathrm{O}$ and $\delta^{2} \mathrm{H}$ increase, even though less than what would be expected from a distillation process. The limited increase is due to the rapid exchange of water molecules between water and vapour, an effect that predominates over the separation effect due to the removal of vapour (Craig et al. 1963; Lloyd 1966). The slope of the evaporation line in a $\delta^{18} \mathrm{O}-\delta^{2} \mathrm{H}$ plot is close to that of the meteoric water line at high air humidity but becomes flatter under more arid conditions (see illustrations in Gonfiantini 1986). Once evaporation reduced the original mass of sea-water to about $20 \%$, the $\delta^{18} \mathrm{O}$ and $\delta^{2} \mathrm{H}$ values loop back towards lower values due to the growing importance of water-ion interactions in the brine (Gonfiantini 1965; Clark and Fritz 1999). Based on surveys in natural salt pans, Lloyd (1966) concluded that $\delta^{18} \mathrm{O}$ values of evaporating sea-water in humid coastal environments do not exceed 6\%ov-smow.

\subsection{Scoping calculations exploring pore-water evolution}

The preceding sections presented evidence for marine incursions followed by partial evaporation in the Aquitanian. Assuming that these brines were also present at Mont Terri and Mont Russelin, the question is if and how they could have infiltrated into the underlying low-permeability sequence. The brine had an elevated density (around $1.08 \mathrm{~cm}^{3} / \mathrm{g}$ at gypsum saturation, $1.22 \mathrm{~cm}^{3} / \mathrm{g}$ at halite saturation; based on calculations with PhreeqC), which may have triggered density-driven infiltration into the karst aquifer of the Malm. From there, diffusive exchange with the low-salinity pore-waters of the underlying low-permeability rocks may have taken place. In the following, an attempt is made to quantify these processes. The Malm aquifer is considered as the upper boundary, which overlies a low-permeability sequence in which transport is dominated by diffusion. The objective is to explore how pore-water composition is affected by chemical changes in the Malm aquifer. Given the fact that the palaeo-hydrogeological evolution is not known accurately and some assumptions needed for the calculations are speculative, the results must be considered as scoping calculations. They are suited to test the plausibility of working hypotheses but are less well constrained than the modelling efforts performed by Mazurek et al. (2011) for the youngest part of the evolution (post-Jura folding). In line with the discussion in the preceding section, the main model assumptions are summarised in Table 4. The calculations consider the time period between the end of the open-marine period (66 Ma, base Tertiary) and the onset of flushing of the hanging-wall aquifer (Dogger) with fresh water at $6 \mathrm{Ma}$. A pore-diffusion coefficient $\mathrm{D}_{\mathrm{p}}\left(\mathrm{Cl}^{-}\right)$of $7 \times 10^{-11} \mathrm{~m}^{2} / \mathrm{s}$ normal to bedding, typical of Opalinus Clay at Mont Terri (Van Loon and Soler 2003; Van Loon et al. 2005a, b), was used for the whole sequence. A modified version of the reactive transport code FLOTRAN (Lichtner 2007), in particular the TRANS90 module, was used. FLOTRAN is a finite-volume code capable of 
Table 4 Overview of the assumed palaeo-hydrogeological evolution and values used for transport modelling of the time period between deposition of Opalinus Clay and the onset of flushing of the Dogger aquifer at $6 \mathrm{Ma}$

\begin{tabular}{|c|c|c|c|c|c|}
\hline Time period & $\begin{array}{l}\text { Age } \\
(\mathrm{Ma})\end{array}$ & $\begin{array}{l}\text { Model } \\
\text { time (Myr) }\end{array}$ & Environment & Data used for modelling & $\begin{array}{l}\text { Significance in model } \\
\text { calculations }\end{array}$ \\
\hline $\begin{array}{l}\text { Jurassic- } \\
\text { Cretaceous }\end{array}$ & $201-66$ & & Open marine & $\begin{array}{l}\mathrm{Cl}^{-} \text {at } 66 \mathrm{Ma}=19.35 \mathrm{~g} / \mathrm{L}, \delta^{18} \mathrm{O}=0 \% 0 \\
\text { throughout the sequence }\end{array}$ & $\begin{array}{l}\text { Initial and upper } \\
\text { boundary condition }\end{array}$ \\
\hline Palaeogene & $66-23$ & $0-43$ & Continental & $\begin{array}{l}\text { Meteoric water }\left(\mathrm{Cl}^{-}=0 \mathrm{~g} / \mathrm{L}\right. \\
\left.\quad \delta^{18} \mathrm{O}=-7.7 \%\right) \text { circulating in Malm } \\
\text { aquifer }\end{array}$ & $\begin{array}{l}\text { Upper boundary } \\
\text { condition }\end{array}$ \\
\hline $\begin{array}{l}\text { Aquitanian (and } \\
\text { younger?) }\end{array}$ & $23-\mathrm{a}$ & $43-b$ & $\begin{array}{l}\text { Hypersaline (partial } \\
\text { evaporation of sea-water) }\end{array}$ & $\begin{array}{l}\mathrm{Cl}^{-}=70-190 \mathrm{~g} / \mathrm{L}, \delta^{18} \mathrm{O}=+6 \% \text { in Malm } \\
\quad \text { aquifer }\end{array}$ & $\begin{array}{l}\text { Upper boundary } \\
\text { condition }\end{array}$ \\
\hline - Late Miocene & $a-6$ & b-60 & Continental & $\begin{array}{l}\text { Meteoric water }\left(\mathrm{Cl}^{-}=0 \mathrm{~g} / \mathrm{L}\right. \\
\delta^{18} \mathrm{O}=-8.6 \% \text { circulating in Malm } \\
\text { aquifer }\end{array}$ & $\begin{array}{l}\text { Upper boundary } \\
\text { condition }\end{array}$ \\
\hline
\end{tabular}

$\mathrm{a}=14.5 \mathrm{Ma} / 19.5 \mathrm{Ma}, \mathrm{b}=51.5 \mathrm{Myr} / 46.5 \mathrm{Myr}$ for model variants considering brine at gypsum saturation $\left(\mathrm{Cl}^{-}=70 \mathrm{~g} / \mathrm{L}\right) / \mathrm{brine}$ at halite saturation $\left(\mathrm{Cl}^{-}=190 \mathrm{~g} / \mathrm{L}\right)$. For the model variant considering brine at gypsum saturation $\left(\mathrm{Cl}^{-}=70 \mathrm{~g} / \mathrm{L}\right), \mathrm{a}=14.5 \mathrm{Ma}, \mathrm{b}=51.5 \mathrm{Myr}$. For the model variant considering brine at halite saturation $\left(\mathrm{Cl}^{-}=190 \mathrm{~g} / \mathrm{L}\right), \mathrm{a}=19.5 \mathrm{Ma}, \mathrm{b}=46.5 \mathrm{Myr}$

describing two-phase flow and transport of water and gas phases coupled to multicomponent solute transport and reaction with aqueous gaseous species and solids in up to three spatial dimensions. Here, only diffusive transport is considered, and boundary conditions (concentrations or isotope ratios at the model boundaries) can be varied over time as required by the palaeo-hydrogeological scenarios under consideration.

The calculation starts at the beginning of the Tertiary (66 Ma), considering a marine $\mathrm{Cl}^{-}$concentration throughout the sequence at that time. The whole Palaeogene is assumed to be a continental period characterised by negligible $\mathrm{Cl}^{-}$concentration in the Malm aquifer. Therefore, out-diffusion of salinity will occur over this period. At the onset of the Aquitanian (23 Ma), a hypersaline upper boundary condition in the Malm aquifer is assumed. Sediments deposited during this period contain gypsum but no halite, suggesting that sea-water at that time evaporated to concentrations in the interval between gypsum and halite saturation. Calculations using the PHREEQC V3 code (Parkhurst and Appelo 2013) with the Pitzer data base indicate that this interval corresponds to $\mathrm{Cl}^{-}$concentrations in the range $70-190 \mathrm{~g} / \mathrm{L}$. The duration of the hypersaline upper boundary condition is treated as a fit parameter, and model runs were performed in the range of 1-10 Myr, leaving all other parameters unchanged. Following the hypersaline stage, a meteoric environment is assumed until the late Miocene (6 Ma), at which time the limestone aquifer in the Passwang Formation has been activated due to exhumation following the formation of the Mont Terri anticline. The model calculations stop at this time, given the fact that the Plioand Pleistocene evolution is complex and has been modelled in detail by Mazurek et al. (2011).
The calculated $\mathrm{Cl}^{-}$concentration profiles at the end of the model time (late Miocene, $6 \mathrm{Ma}$ ) considering a brine composition of $70 \mathrm{~g} / \mathrm{L}$ for the hypersaline period are shown in Fig. 10a. In order to approach the $\mathrm{Cl}^{-}$concentration of $18.4 \mathrm{~g} / \mathrm{L}$ found in the stagnant ground-water in the Beggingen Member (Staffelegg Formation) at Mont Russelin, a duration for the hypersaline episode in the early Miocene of $8.5 \mathrm{Myr}$ is required, i.e. it exceeds the duration of the Aquitanian. Assuming a brine composition corresponding to halite saturation shortens the best-fit time to $3.5 \mathrm{Ma}$ (not shown). Figure 10b shows the modelled evolution of $\mathrm{Cl}^{-}$ in the model case considering a hypersaline boundary with $\mathrm{Cl}^{-}=70 \mathrm{~g} / \mathrm{L}$ in detail. During the Palaeogene (model time $0 \mathrm{Myr}=66 \mathrm{Ma}$ ), out-diffusion leads to progressively decreasing $\mathrm{Cl}^{-}$concentrations. After $43 \mathrm{Myr}$ (end of the Palaeogene), the $\mathrm{Cl}^{-}$concentration at the depth level of Opalinus Clay was 9-11 g/L, about half the original value. This means that $\mathrm{Cl}^{-}$concentration must have been increased at later stages to reach the maximum values observed today $(14 \mathrm{~g} / \mathrm{L}$ at Mont Terri, $22 \mathrm{~g} / \mathrm{L}$ at Mont Russelin; see Fig. 2). This increase can be achieved by the propagation of a $8.5 \mathrm{Myr}$ long hypersaline pulse to depth, as shown in Fig. 10b. The final profile after $60 \mathrm{Myr}$ running time (late Miocene, $6 \mathrm{Ma}$ ) is rather flat.

The same model scenario that was used for $\mathrm{Cl}^{-}$above can also be applied to $\delta^{18} \mathrm{O}$ in pore-water (details in Table 4). A diffusion coefficient $D_{p}$ (HTO) normal to bedding of $1.2 \times 10^{-10} \mathrm{~m}^{2} / \mathrm{s}$ (Van Loon and Soler 2003; Van Loon et al. 2005a, b) was used. The upper boundary condition for the model calculations changed over time in response to evolving environmental conditions. Given the fact that Tertiary climate was warmer than today, the isotopic composition of precipitation had higher $\delta$ values. The time-temperature relationship of Zachos et al. (2008) and 

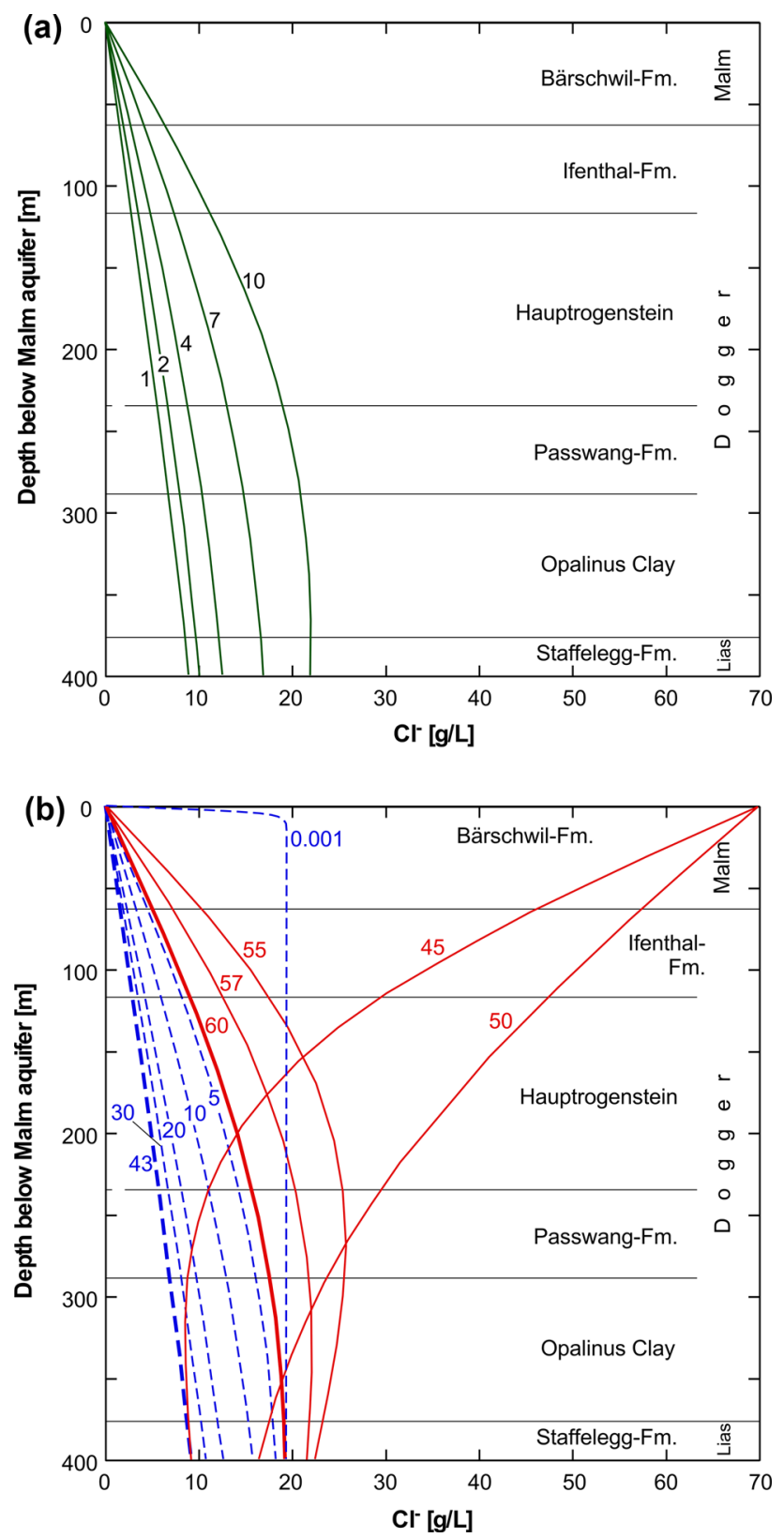

Fig. 10 Results of model calculations considering diffusive exchange of $\mathrm{Cl}^{-}$between the Malm aquifer (upper boundary condition) and the underlying low-permeability sequence. The scenario considers a $\mathrm{Cl}^{-}$ concentration of $70 \mathrm{~g} / \mathrm{L}$ at the upper boundary for the duration of the hypersaline period. Stratigraphic profile according to Freivogel and Huggenberger (2003). a Modelled final $\mathrm{Cl}^{-}$concentrations in the late Miocene (6 Ma), considering different durations for the hypersaline upper boundary condition in the early Miocene. Numbers indicate the durations for this condition in Myr. b Evolution of $\mathrm{Cl}^{-}$concentrations for a model considering a hypersaline stage lasting $8.5 \mathrm{Myr}$. Numbers indicate evolution times in Ma since the onset of the Tertiary (66 Ma). Broken blue lines represent the Palaeogene evolution, solid red lines refer to the Neogene

Hansen et al. (2013) indicates that mean global temperatures were 8.1 and $4.4{ }^{\circ} \mathrm{C}$ higher than today during the Palaeogene and the Neogene, respectively. Several authors explored the dependence of $\delta^{18} \mathrm{O}$ in meteoric water on surface temperature, mainly on the basis of noble-gas infiltration temperatures in ground-waters (Pearson et al. 1991; Stute and Schlosser 2000; overview in Mazurek et al. 2009, Appendix A4.1). For central Europe, Huneau (2000) and Philippot et al. (2000) obtained an average dependence of $0.24 \%$ / ${ }^{\circ} \mathrm{C}$. Based on this, $\delta^{18} \mathrm{O}$ is estimated to be $1.95 \%$ and $1.05 \%$ higher than today for the Palaeogene and Neogene, respectively. Considering the current average $\delta^{18} \mathrm{O}$ of recent ground-waters at Mont Terri and Mont Russelin $\left(-9.67 \%{ }^{0}\right.$ v-smow $)$ yields $\delta^{18} \mathrm{O}$ of $-7.7 \%{ }^{0 \mathrm{~V}-\mathrm{SmOw}}$ for the Palaeogene and $-8.6 \%{ }^{\circ}$-smow for the Neogene. These values were used as the upper boundary condition for the model calculation during continental periods (Table 4). For the hypersaline stage, a $\delta^{18} \mathrm{O}$ of $+6 \% \mathrm{ov}$ sMow was assumed on the basis of values measured in natural salt pans by Lloyd (1966), a topic further discussed in Sect. 5.4 above. The calculation considering hypersaline conditions over a period of $8.5 \mathrm{Myr}$ yields $\delta^{18} \mathrm{O}=-5.7$ to $-5.2 \%$ at the end of the Palaeogene (after 43 Myr running time) for Opalinus Clay. After the total running time of $60 \mathrm{Myr}(6 \mathrm{Ma})$, a $\delta^{18} \mathrm{O}$ in the range -3.5 to $-4.3 \%$ is obtained. This range shifts slightly (max. $0.5 \%$ ) towards more negative values when the duration of the hypersaline period is reduced to $3.5 \mathrm{Myr}$.

\subsection{Plausibility of a Tertiary component in waters of the low-permeability sequence}

Figure 11 illustrates the results of the model calculations, together with measured data and the assumed sea-water evaporated until gypsum saturation (point $2: \mathrm{Cl}^{-}=70 \mathrm{~g}$ / $\mathrm{L}, \delta^{18} \mathrm{O}=+6 \%$ v-smow). The modelled $\mathrm{Cl}^{-}$concentrations and $\delta^{18} \mathrm{O}$ values for Opalinus Clay are shown as point 3 (end Palaeogene) and point 4 (upper Miocene, $6 \mathrm{Ma}$ ). Note that point 4 is slightly above the line connecting points 2 and 3 , which is due to the different diffusion coefficients for $\mathrm{Cl}^{-}$and $\delta^{18} \mathrm{O}$. Point 4 is quite close to the value of the deep ground-water at Mont Russelin, supporting the hypothesis that this water can be rationalised as a mixture of pore-water residing in the formation at the end of the Palaeogene (point 3) and a partially evaporated seawater that diffused down into the low-permeability sequence.

In principle, the proposed mechanism is capable of explaining the composition of the deep ground-water at Mont Russelin, which is considered to represent the porewater composition prior to activation of the aquifers in the Passwang Formation and the Beggingen Member (Staffelegg Formation). The involvement of a component of evaporated sea-water is required to explain the departure of the Mont Russelin water from the mixing line between seawater and meteoric water (see Fig. 11), and the calculated 


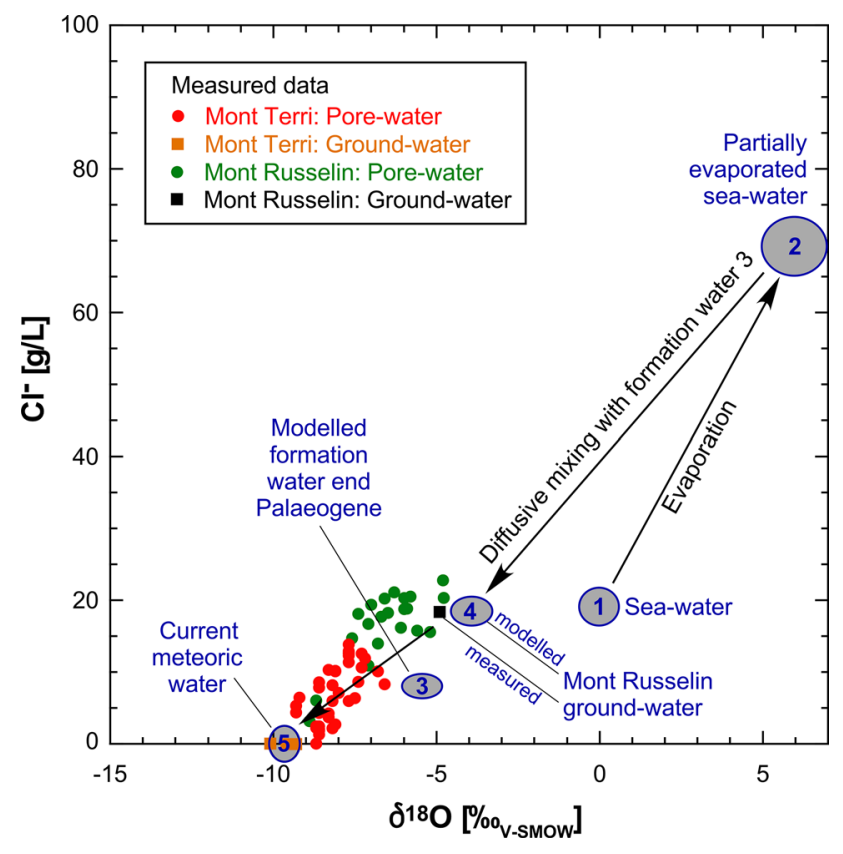

Fig. 11 Diagram of $\delta^{18} \mathrm{O}$ versus $\mathrm{Cl}^{-}$illustrating the hypothetical path of sea-water evaporated to gypsum saturation, later mixing with meteoric water

duration for the hypersaline period is 3.5-8.5 Ma when considering diffusive transport alone. The main question that remains is how the hypersaline water penetrated the low-permeability sequence. It is difficult at this stage to qualify the geological plausibility of a hypersaline episode lasting several Myr, even though it appears to lie within the possible spectrum.

While the model calculations assumed diffusion as the only process, the possibility exists that at least in limestones, such as the Hauptrogenstein, an advective component may have enhanced solute transport. Further, faults related to the Rhine Graben system were active at that time and may have provided at least transient short circuits. Such structures are also known in the Mont Terri rock laboratory (Nussbaum et al. 2011). An advective component at least in some units would lead to more rapid transport of salinity and so would shorten the calculated duration of the hypersaline event.

Further, there are independent arguments supporting the presence of a Tertiary marine component:

- The isotopic composition of $\mathrm{SO}_{4}{ }^{2-}$ in pore-water at Mont Terri falls into the narrow field of Miocene seawater (Fig. 6). It lies outside the ranges for Jurassic and Cretaceous sea-waters, and it also cannot be derived from these waters via partial reduction. Given the fact that most of the $\mathrm{SO}_{4}{ }^{2-}$ present in the sediments at the time of deposition was lost by bacterial reduction during early diagenesis (uppermost decimetres of the sediment below the sea floor; see Raiswell and Canfield
2012) and precipitated as pyrite, the absence of a Jurassic isotope signature is plausible.

- $\mathrm{The}{ }^{87} \mathrm{Sr} /{ }^{86} \mathrm{Sr}$ ratio in pore-water and that of $\mathrm{Sr}$ sorbed on clay minerals is substantially higher than the ratio of connate late Toarcian/Aalenian water (Fig. 7). However, it can be well explained as a mixture of connate water and a Tertiary sea-water component.

In conclusion, the suggested mixing of waters can explain the fact that the waters at Mont Terri and Mont Russelin have marine signatures on the one hand and the seemingly inconsistent mixing proportions of meteoric water on the other hand. The time needed to equilibrate the low-permeability sequence with a sea-water derived karst groundwater in the Malm is on the long end of what is plausible from a geological perspective. Possible advective transport at least in the competent limestone units would shorten transport times.

The late Chattian/Aquitanian marine incursions are known from the external parts of the Folded Jura but not from more eastern regions. It is worth noting that while $\mathrm{Cl}^{-} / \mathrm{Br}^{-}$ratios at Mont Terri and Mont Russelin are close to marine values (around $290 \mathrm{~g} / \mathrm{g}$ ), this is not the case for Opalinus Clay in the more eastern parts of northern Switzerland where values up to 1000 are observed (borehole Schlattingen: Mazurek et al. 2015; boreholes Weiach, Riniken, Schafisheim: Meier and Mazurek 2011). Here, the $\mathrm{Cl}^{-} / \mathrm{Br}^{-}$ratio points to non-marine components of salinity, e.g. originating from halite dissolution.

\subsection{Vein infills as records of fluids circulating during the formation of the Jura Fold and Thrust Belt}

The potential effects of the formation of the Jura Fold and Thrust Belt include (1) transient advective fluid flow triggered by deformation events, and (2) the creation of topography, leading to erosion, exhumation of aquifers and activation of fluid circulation in these. Transient syntectonic fluid flow is recorded by vein infills. There are only few and thin veins in Opalinus Clay at Mont Terri, most of them in and around the Main Fault. Flow was spatially focussed to discrete structures and to temporally limited time scales, most probably linked to seismo-tectonic movements along faults (see e.g. Cox 2005). At present, brittle structures at Mont Terri are hydraulically indistinguishable from the rock matrix (Meier et al. 2002), suggesting an efficient self-sealing mechanism (Bock et al. 2010; Fisher et al. 2013). Further, profiles of conservative pore-water tracers $\left(\mathrm{Cl}^{-}, \mathrm{Br}^{-}, \mathrm{He}, \delta^{37} \mathrm{Cl}, \delta^{18} \mathrm{O}, \delta^{2} \mathrm{H}\right)$ do not show any evident perturbation near or within the Main Fault, further supporting the hydraulic irrelevance of this 
structure at present time (Pearson et al. 2003; Mazurek et al. 2009, 2011).

\subsubsection{Evidence based on isotopes of $\mathrm{SO}_{4}{ }^{2-}$ and of the ${ }^{87} \mathrm{Sr} /{ }^{86} \mathrm{Sr}$ ratio}

Figure 6 illustrates the available $\mathrm{S}$ and $\mathrm{O}$ isotope data from sulphate in celestite as well as pore-waters. It further shows the ranges of the global evolution of $\delta^{34} \mathrm{~S}$ and $\delta^{18} \mathrm{O}$ in marine sulphate over geological time according to Claypool et al. (1980) and, for the Miocene, the values for northern Switzerland obtained by Balderer et al. (1991). The range of values for celestite from Mont Terri is outside the field of marine sulphate at all times at which sea-water was potentially present in the region, which means that the sulphate isotopes must have been affected by more recent processes, such as microbially mediated reactions. Figure 6 shows that the data can be explained by partial reduction of sulphate originating in the underlying evaporites of the Keuper, leading to enrichment of the heavy isotopes in the residual sulphate. The slope of this enrichment in a plot of $\delta^{34} \mathrm{~S}$ versus $\delta^{18} \mathrm{O}$ varies as a function of various factors (bacterial vs. abiotic reduction, open vs. closed system, effects of Rayleigh distillation) but mostly lies in the range 0.25-0.4 (Pierre 1989; Clark and Fritz 1999). As shown in Fig. 6, a slope of 0.4 reasonably well fits the trend of vein celestite with sulphate originating in the Keuper evaporites. The importance of sulphate reduction prior or during vein formation is also documented by the occurrence of pyrite as vein infill.

As shown in Fig. 7, the ${ }^{87} \mathrm{Sr} /{ }^{86} \mathrm{Sr}$ ratio in veins coincides with the corresponding values for $\mathrm{Sr}$ sorbed on clay minerals as given by Lerouge et al. (2010), as well as with those in current pore-water (data from Pearson et al. 2003). It therefore appears likely that sulphate-rich waters migrating upwards from the Keuper during deformation events linked to the formation of the anticline reacted with $\mathrm{Sr}$ already present in Opalinus Clay, either in pore-water or on cation-exchange sites of clay minerals. It was suggested in Sect. 5.6 that this $\mathrm{Sr}$ is best interpreted as a mixture of connate $\mathrm{Sr}$ and $\mathrm{Sr}$ derived from a Tertiary sea-water.

\subsubsection{Temperature of vein formation}

The $\delta^{18} \mathrm{O}$ values of vein calcite are lower when compared to whole-rock carbonate (Fig. 5). Provided the isotopic composition of the water from which vein calcite precipitation is known, the temperature of vein crystallisation can be determined. However, given the fact that current pore-water is strongly affected by diffusive exchange with the surrounding aquifer waters since Jura deformation (Mazurek et al. 2011), its composition at that time cannot be easily constrained. The best proxy for such a water is considered to be the deep stagnant ground-water at Mont Russelin (see Sect. 2.3). Taking its $\delta^{18} \mathrm{O}$ value of $-4.9 \%{ }^{0} \mathrm{~V}$-SMow, temperatures in the range $37-47{ }^{\circ} \mathrm{C}$ can be calculated for the precipitation of the calcite veins in and immediately around the Main Fault, using the fractionation factor of O'Neil et al. (1969). This range is below the maximum temperature of Miocene burial of $55{ }^{\circ} \mathrm{C}$ obtained by Mazurek et al. (2006). On the other hand, if one would assume the presence of seawater $\left(\delta^{18} \mathrm{O}=0 \%\right.$ ) at the time of vein precipitation during folding and thrusting, the calculated temperature of vein formation would lie in the range $68-81{ }^{\circ} \mathrm{C}$, i.e. well above the maximum burial temperature during the Miocene. On this basis, it is concluded that the water from which the veins precipitated must have had a negative $\delta^{18} \mathrm{O}$ value.

Two measurements of $\delta^{18} \mathrm{O}$ of vein calcite are also available from Mont Russelin, with even lower values of 17.1 and $17.4 \%$ v-smow (Table 2). Assuming precipitation from a water with $\delta^{18} \mathrm{O}=-4.9 \%{ }^{\circ}$-SMow yields a temperature of $59-61{ }^{\circ} \mathrm{C}$, close to the maximum temperature of Miocene burial.

Values for $\delta^{13} \mathrm{C}$ of vein calcite show a wide range of variability (about -7 to $1 \%$ v-PDB, see Table 2 ). The values are close to or lower than those of whole-rock carbonate. In the Main Fault and its immediate surroundings, $\delta^{13} \mathrm{C}$ of vein calcite is lower by $0.8 \%$ compared to whole-rock carbonate.

\subsection{Effect of fluid related to vein precipitation on bulk pore-water}

Sulphate isotopes in celestite and in current pore-water occupy different fields in Fig. 6 and appear to be genetically unrelated. The question arises to what degree faultrelated fluid flow recorded in the veins affected the porewater chemistry in the bulk rock matrix of Opalinus Clay. The movements related to thrusting were likely shallow seismo-tectonic events. Various authors characterised the hydrogeological consequences of such events (e.g. MuirWood and King 1993; Wang and Manga 2010). Fluid flow and geochemical disturbances have been observed over no longer than days to years. Further, self-sealing (Marschall et al. 2008; Bock et al. 2010; Fisher et al. 2013) is expected to occur in clay-rich lithologies containing swelling clay minerals, such as the low-permeability sequence at Mont Terri and Mont Russelin, suggesting that fluid pulses were likely short-lived.

In order to quantify the diffusive propagation of a geochemical perturbation from a permeable structure into the adjacent rock matrix, simple design calculations were made considering simple in-diffusion from a boundary with time-invariant composition into an infinite half-space. This 
scenario can be explored using an analytical solution taken from Carslaw and Jaeger (1973)

$$
\frac{C}{C_{0}}=\operatorname{erfc}\left(\frac{x}{2 \sqrt{D_{p} t}}\right) \text {. }
$$

This equation relates concentration $C$ at time $t$ with the distance $x$ from the boundary, with $D_{p}=$ pore-diffusion coefficient and $C_{0}=$ invariant concentration at the boundary. $\mathrm{Cl}^{-}$is taken as an example species, using a diffusion coefficient $D_{p}=2 \times 10^{-10} \mathrm{~m}^{2} / \mathrm{s}$ parallel to bedding (Van Loon and Soler 2003). As shown in Fig. 12, even over $100 \mathrm{y}$ the disturbance propagates only a few $\mathrm{m}$ into the rock. Given the scarcity of vein infills at Mont Terri and Mont Russelin, episodically permeable structures are infrequent and mostly linked to widely-spaced major faults. Therefore, spatially and temporally limited advection across Opalinus Clay affects only a minor volume fraction of the total volume of the formation. Once flow ceases and the fracture self-seals, the geochemical disturbance in the rock matrix will be obliterated by diffusion over geologically short time scales. It is concluded that limited fluid flow across discrete but infrequent structures is not expected to greatly affect the bulk composition of pore-water in the formation. This explains why sulphate isotopes of vein infills and current pore-water are unrelated, and why pore-waters have a marine signature today $\left(\mathrm{Cl}^{-} /\right.$ $\mathrm{Br}^{-}$ratio), in spite of later fluid flow during Jura deformation.

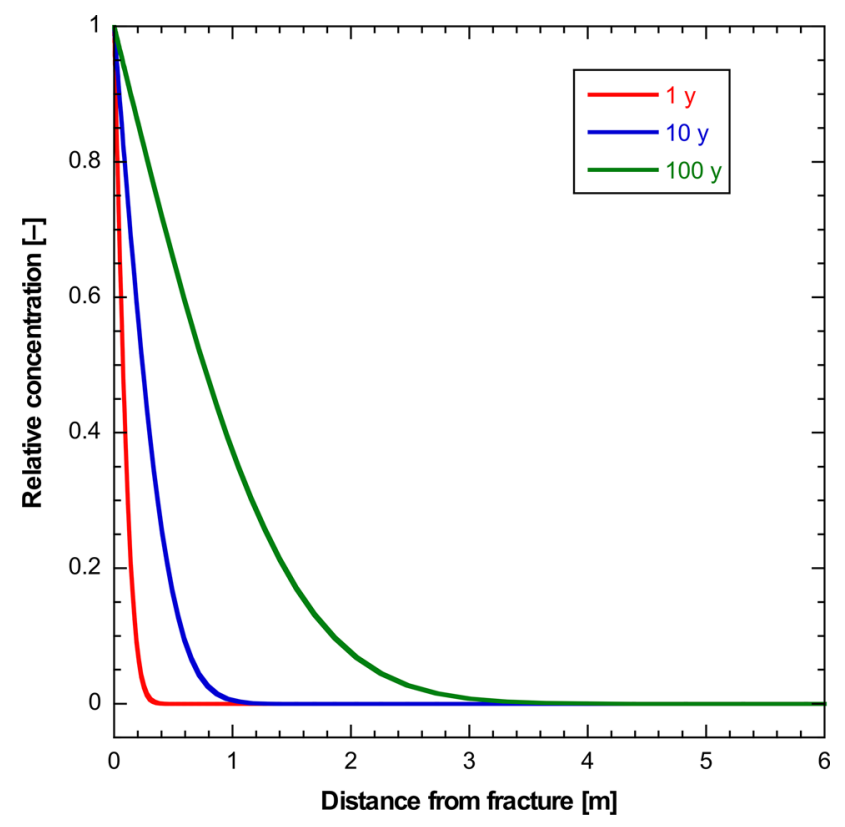

Fig. 12 Diffusive propagation of a geochemical perturbation from a fracture into the rock matrix

\subsection{Evolution since Jura folding}

Apart from geochemical disturbances localised in active faults, the formation of the Jura Fold and Thrust Belt created a substantial topography that enhanced erosion, in particular of the anticlinal structures. Erosion led to the exhumation of limestone aquifers at Mont Terri and, to a lesser degree, at Mont Russelin. Exhumation initiated the flushing of the aquifers with meteoric water, which established new geochemical boundary conditions on both sides (Mont Terri) or on top (Mont Russelin) of the low-permeability sequence. Diffusion since the time of aquifer flushing led to the curved tracer profiles that are observed today (e.g. Figure 2). Model calculations of Mazurek et al. (2011) successfully reproduced the present-day profiles considering diffusion alone, and the calculated evolution times were consistent with independent palaeo-hydrogeological evidence. The mixing process is illustrated by points 4 and 5 in Fig. 11.

\section{Conclusions}

Pore-waters in clay-rich aquitards are geochemical archives with a much longer memory than ground-waters in more permeable units. This is due to the fact that diffusion is the dominating mechanism of mass transport, leading to slow adjustment to changing conditions in the adjacent aquifers. At Mont Terri and Mont Russelin, porewaters have a marine component, highlighted by the $\mathrm{Cl}^{-}$/ $\mathrm{Br}^{-}$ratio and the isotopic composition of $\mathrm{SO}_{4}{ }^{2-}$. The marine signature probably reflects sea-water incursions at the Oligocene/Miocene boundary (about $23 \mathrm{Ma}$ ).

The most complete chemical and isotopic data set can be obtained from waters sampled in long-term in situ experiments, and it is complemented by laboratory data obtained from measurements on drillcores. While the latter are more numerous, they typically yield only partial information on pore-water composition. Isotopic data obtained from calcite and celestite in veins are another source of information, providing insights into the composition of the fluid at the time of vein formation. On the basis of this data set, together with independent knowledge on regional geology and hydrogeology, the following evolution is proposed:

- Deposition of the Jurassic-Cretaceous rocks occurred in a sedimentary basin under open-marine conditions. Pore-waters in the sedimentary pile were likely similar to sea-water. Diagenetic effects modified some components, e.g. $\mathrm{SO}_{4}{ }^{2-}$ was reduced and is present as pyrite today.

- Towards the end of the Cretaceous, the basin was inverted, leading to continental conditions throughout the Palaeogene. Erosion removed Cretaceous rocks 
completely and led to karstification in the limestones of the Malm (upper Jurassic), which became a regional aquifer. Given the existence of a fresh-water regime in the Malm over tens of Myr, out-diffusion of dissolved ions led to a decrease of salinity in the underlying lowpermeability sequence. Model calculations indicate that at the level of the Opalinus Clay, salinity was about half that of sea-water at the end of the Palaeogene. This is less than in the most saline waters present today at Mont Terri and Mont Russelin, so an increase of salinity must have taken place at more recent times.

- During the deposition of the Lower Freshwater Molasse, marine incursions from the northwest occurred in the external parts of the Folded Jura and led to the deposition of gypsiferous evaporites (about $23 \mathrm{Ma}$, late Chattian/early Aquitanian). It is suggested that hypersaline waters derived from partially evaporated sea-water infiltrated the Malm aquifer and so drastically changed the upper boundary condition for the underlying pore-waters.

- Model calculations considering diffusive transport alone indicate that the time needed to attain the salinity level in Opalinus Clay observed today is in the range 3.5-8.5 Ma. There are no independent arguments in support of such a long duration for the brine regime at the upper boundary condition, so this mechanism remains hypothetical. Nevertheless, isotopes of $\mathrm{SO}_{4}{ }^{2-}$ are consistent with a Miocene marine source and would be difficult to explain otherwise. The ${ }^{87} \mathrm{Sr} /{ }^{86} \mathrm{Sr}$ ratio is consistent with a mixture of connate and Miocene Sr. Further, the in-diffusion of partially evaporated sea-water potentially explains the observation that pore-waters at Mont Terri and Mont Russelin cannot be interpreted as simple binary mixtures of sea and meteoric water-the proportion of a meteoric component based on halogen concentrations is consistently lower than that obtained from stable water isotopes. During sea-water evaporation, the concentrations of halogens increase linearly until halite saturation is reached. In contrast, $\delta^{18} \mathrm{O}$ and $\delta^{2} \mathrm{H}$ behave non-linearly, depending on the climatic conditions.

- Following the hypersaline stage, meteoric conditions and therefore a fresh-water upper boundary prevailed until the onset of deformation related to the formation of the Jura Fold and Thrust Belt in the uppermost Miocene. At that time, limited and transient flow along active faults occurred and led to the formation of calcite-celestite veins. According to the isotopic signature of sulphate in celestite, the fluids originate in the underlying Triassic evaporites. $\mathrm{SO}_{4}{ }^{2-}$ was partially reduced during transport, evidenced by the isotopic trends and the presence of pyrite in the veins. Veins are scarce and mostly associated to major thrust structures. Flow in these structures was limited spatially and temporally and did not affect the bulk pore-water in the rock matrix. This is also highlighted by the preservation of a marine $\mathrm{Cl}^{-} / \mathrm{Br}^{-}$ratio in the pore-water as well as of its isotopic composition of $\mathrm{SO}_{4}{ }^{2-}$, which has a Miocene signature and differs substantially from that in vein celestite. Vein precipitation occurred at temperatures of $35-45^{\circ} \mathrm{C}$ at Mont Terri, possibly at somewhat higher temperatures at Mont Russelin.

- After the formation of the anticlinal structures, erosion activated the aquifers above (Mont Terri, Mont Russelin) and below (only Mont Terri) the low-permeability sequence, where fresh-water conditions were established and are still present today. This last change in boundary conditions led to the development of the curved profiles of $\mathrm{Cl}^{-}, \mathrm{Br}^{-}, \delta^{18} \mathrm{O}, \delta^{2} \mathrm{H}$ and $\mathrm{He}$ that are observed today.

- While the proposed model of pore-water evolution is consistent with a range of independent lines of evidence, some uncertainty remains that cannot be further reduced at this stage. The main points include the composition and residence time of the Miocene brine that is suggested as a source of salinity for the underlying low-permeability sequence, and the isotopic composition of precipitation during the Tertiary.

Acknowledgements We thank Paul Wersin, Albert Matter (both Uni. Bern) and Andreas Gautschi (Nagra) for useful discussions. Detailed and constructive reviews by A. Bath (Intellisci, UK) and J. M. Matray (IRSN, France) helped to improve the manuscript.

Open Access This article is distributed under the terms of the Creative Commons Attribution 4.0 International License (http://crea tivecommons.org/licenses/by/4.0/), which permits unrestricted use, distribution, and reproduction in any medium, provided you give appropriate credit to the original author(s) and the source, provide a link to the Creative Commons license, and indicate if changes were made.

\section{References}

Afconsult. (2012). HA-experiment: Hydraulic database phases 1-16. Mont Terri Technical Note, TN 2010-74, 20 pp. Federal Office of Topography (swisstopo), Wabern. www.mont-terri.ch.

Aubry, M. P., Van Couvering, J. A., Christie-Blick, N., Landing, E., Pratt, B. R., Owen, D. E., et al. (2009). Terminology of geological time: Establishment of a community standard. Stratigraphy, 6, 100-105.

Balderer, W., Pearson, F. J., \& Soreau, S. (1991). Sulphur and oxygen isotopes in sulphate and sulphide. In F. J. Pearson, W. Balderer, H. H. Loosli, B. E. Lehmann, A. Matter, T. Peters, H. Schmassmann \& A. Gautschi (Eds.), Applied isotope hydrology: A case study in northern Switzerland (pp. 227-242). Studies in Environmental Science, vol. 43. Amsterdam: Elsevier.

Becker, A. (2000). The Jura Mountains-An active foreland fold-andthrust belt? Tectonophysics, 321, 381-406. 
Becker, D., \& Berger, J. P. (2004). Paleogeography of the Swiss Molasse Basin and the Upper Rhine Graben during the Late Burdigalian and Langhian. Courier Forschungsinstitut Senckenberg, 249, 1-13.

Berger, J. P. (1996). Cartes paléogéographiques-palinspastiques du bassin molassique suisse (Oligocène inférieur-Miocène moyen). Neues Jahrbuch für Geologie und Paläontologie-Abhandlungen, 202, 1-44.

Berger, J. P., Reichenbacher, B., Becker, D., Grimm, M., Grimm, K., Picot, L., et al. (2005). Paleogeography of the Upper Rhine Graben (URG) and the Swiss Molasse Basin (SMB) from Eocene to Pliocene. International Journal of Earth Sciences, 94, 697-710.

Bock H., Dehandschutter, B., Martin, C. D., Mazurek, M., de Haller, A., Skoczylas, F., et al. (2010). Self-sealing of fractures in argillaceous formations in context with the geological disposal of radioactive waste. OECD/NEA Report, 6184, 310 pp. OECD, Paris, France. www.oecdbookshop.org.

Bossart, P., Bernier, F., Birkholzer, J., Bruggeman, C., Connolly, P., Dewonck, S., Fukaya, M., Herfort, M., Jensen, M., Matray, J-M., Mayor, J. C., Moeri, A., Oyama, T., Schuster, K., Shigeta, N., Vietor, T., \& Wieczorek, K. (2017). Mont Terri rock laboratory, 20 years of research: introduction, site characteristics and overview of experiments. Swiss Journal of Geosciences, 110. doi:10.1007/s00015-016-0236-1 (this issue).

Bossart, P., \& Thury, M. (2007). Research in the Mont Terri rock laboratory: Quo vadis? Physics and Chemistry of the Earth, 32, $19-31$.

Bureau Technique Norbert. (1993). Tunnel du Mont Russelin-Profil en long géologique. Unpublished document.

Carslaw, H. S., \& Jaeger, J. C. (1973). Conduction of heat in solids (2nd ed.). Oxford: Clarendon Press.

Clark, I., \& Fritz, P. (1999). Environmental isotopes in hydrogeology (2nd printing, 328 pp.). Boca Raton: CRC Press.

Claypool, G. E., Holser, W. T., Kaplan, I. R., Sakai, H., \& Zak, I. (1980). The age curves of sulfur and oxygen isotopes in marine sulfate and their mutual interpretation. Chemical Geology, 28, $199-260$

Cohen, K. M., Finney, S. C., Gibbard, P. L., \& Fan, J. X. (2013). The ICS international chronostratigraphic chart. Episodes, 36, 199-204.

Cox, S. F. (2005). Coupling between deformation, fluid pressure, and fluid flow in ore producing hydrothermal systems at depth in the crust. Economic Geology, 100, 39-75.

Craig, H., \& Gordon, L. I. (1965). Deuterium and oxygen-18 variations in the ocean and marine atmosphere. In E. Tongiorgi (Ed.), Stable isotopes in oceanographic studies and paleotemperatures (pp. 161-182). Pisa: Consiglio Nazionale delle Ricerche, Laboratorio de Geologia Nucleare.

Craig, H., Gordon, L., \& Horibe, Y. (1963). Isotopic exchange effects in the evaporation of water. Journal of Geophysical Research, 68, 5079-5087.

De Haller, A., Mazurek, M., Spangenberg, J., \& Möri, A. (2014). SF (Self-sealing of faults and paleo-fluid flow): Synthesis report. Mont Terri Technical Report, TR 08-02, 63 pp. Federal Office of Topography (swisstopo), Wabern, Switzerland. www.mont-terri. ch.

Fisher, Q., Kets, F., \& Crook, A. (2013). Self-sealing of faults and fractures: Evidence from the petroleum industry. Nagra Arbeitsbericht, NAB 13-06, 231 pp. Nagra, Wettingen. www.nagra.ch.

Freivogel, M., \& Huggenberger, P. (2003). Modellierung bilanzierter Profile im Gebiet Mont Terri-La Croix (Kanton Jura). In P. Heitzmann \& J. P. Tripet (Eds.), Mont Terri project-Geology, paleohydrology and stress field of the Mont Terri region (pp. 7-44). Reports of the Federal Office for Water and Geology,
Geology Series, No. 4. Federal Office of Topography (swisstopo), Wabern. www.mont-terri.ch.

Gomez, J. J., Canales, M. L., Ureta, S., \& Goy, A. (2009). Palaeoclimatic and biotic changes during the Aalenian (Middle Jurassic) at the southern Laurasian Seaway (Basque-Cantabrian Basin, northern Spain). Palaeogeography, Palaeoclimatology, Palaeoecology, 275, 14-27.

Gonfiantini, R. (1965). Effetti isotopici nell'evaporazione di acque salate. Atti della Società Toscana di Scienze Naturali, Serie A, 72, 550-569.

Gonfiantini, R. (1986). Environmental isotopes in lake studies. In P. Fritz \& J. C. Fontes (Eds.), Handbook of environmental isotope geochemistry (Vol. 2, pp. 113-168)., The terrestrial environment, B Burlington: Elsevier.

Hansen, J., Sato, M., Russell, G., \& Kharecha, P. (2013). Climate sensitivity, sea level and atmospheric carbon dioxide. Philosophical transactions of the Royal Society A, 371, 20120294.

Huneau, F. (2000). Fonctionnement hydrogéologique et archive paléoclimatique d'un aquifère profond méditerranéen. Ph.D. dissertation, University of Avignon, Avignon.

Kissling, D. (1974). L'Oligocène de l'extrémité occidentale du bassin molassique suisse. Stratigraphie et aperçu molassique. Ph.D dissertation, Université de Genève, Genève.

Koroleva, M., Alt-Epping, P., \& Mazurek, M. (2011). Large-scale tracer profiles in a deep claystone formation (Opalinus Clay at Mont Russelin, Switzerland): Implications for solute transport processes and transport properties of the rock. Chemical Geology, 280, 284-296.

Korte, C., Hesselbo, S. P., Ullmann, C. V., Dietl, G., Ruhl, M., Schweigert, G., et al. (2015). Jurassic climate mode governed by ocean gateway. Nature Communications. doi:10.1038/ ncomms 10015 .

Kuhlemann, J., \& Kempf, O. (2002). Post-Eocene evolution of the North Alpine Foreland Basin and its response to Alpine tectonics. Sedimentary Geology, 152, 45-78.

Lerouge, C., Gaboreau, S., Blanc, P., Guerrot, C., Haas, H., JeanProst, V., et al. (2010). PC experiment: Mineralogy and geochemistry of cores of the BPC 935 borehole. Mont Terri Technical Note, TN 2010-05, 46 pp. Federal Office of Topography (swisstopo), Wabern. www.mont-terri.ch.

Lichtner, P. C. (2007). FLOTRAN Users Manual: Two-phase nonisothermal coupled thermal-hydrologic-chemical (THC) reactive flow and transport code, Version 2. LANL report, LA-UR-012349, 173 pp. Los Alamos National Laboratory, Los Alamos, NM.

Lloyd, R. M. (1966). Oxygen isotope enrichment of sea water by evaporation. Geochimica et Cosmochimica Acta, 30, 80-814.

Lorenz, G. \& Vogt, T. (2014). WS-I Experiment-Chemical analyses of BBB-3 water samples collected before pressure build up and during constant rate withdrawal hydro-testing. Mont Terri Technical Note, TN 2013-89, 4 pp. Federal Office of Topography (swisstopo), Wabern. www.mont-terri.ch.

Marschall, P., Croisé, J., Schlickenrieder, L., Boisson, J. Y., Vogel, P., \& Yamamoto, S. (2003). Synthesis of hydrogeological investigations at the Mont Terri site (phases 1 to 5). Mont Terri Technical Report, TR 2001-02, 116 pp. Federal Office of Topography (swisstopo), Wabern. www.mont-terri.ch.

Marschall, P., Trick, T., Lanyon, G. W., Delay, J., \& Shao, H. (2008). Hydro-mechanical evolution of damaged zones around a microtunnel in a claystone formation of the Swiss Jura Mountains. In 42nd US Rock Mechanics Symposium (USRMS), American Rock Mechanics Association.

Mazurek, M., Alt-Epping, P., Bath, A., Gimmi, T., \& Waber, H. N. (2009). Natural tracer profiles across argillaceous formations: The CLAYTRAC project. OECD/NEA Report, 6253, 361 pp. OECD Publishing, Paris. www.oecdbookshop.org. 
Mazurek, M., Alt-Epping, P., Bath, A., Gimmi, T., Waber, H. N., Buschaert, S., et al. (2011). Natural tracer profiles across argillaceous formations. Applied Geochemistry, 26, 1035-1064.

Mazurek, M., Hurford, A. J., \& Leu, W. (2006). Unravelling the multi-stage burial history of the Swiss Molasse Basin: Integration of apatite fission track, vitrinite reflectance and biomarker isomerisation analysis. Basin Research, 18, 27-50.

Mazurek, M., Oyama, T., Wersin, P., \& Alt-Epping, P. (2015). Porewater squeezing from indurated shales. Chemical Geology, 400, $106-121$.

McArthur, J. M., Howarth, R. J., \& Shields, G. A. (2012). Strontium Isotope Stratigraphy. The Geologic Time Scale, 1, 127-144.

Meier, D. \& Mazurek, M. (2011). Ancillary rock and pore-water studies on drillcores from northern Switzerland. Nagra Arbeitsbericht, NAB 10-21, 60 pp. Nagra, Wettingen. www.nagra.ch.

Meier, P. M., Trick, T., Blümling, P., \& Volckaert, G. (2002). Selfhealing of fractures within the EDZ at the Mont Terri Rock Laboratory: Results after one year of experimental work. In N. Hoteit, K. Su, M. Tijani, \& J. F. Shao (Eds.), Proceedings of international workshop on geomechanics, hydromechanical and thermohydro-mechanical behaviour of deep argillaceous rocks: Theory and experiment (pp. 267-274). Paris, France.

Mojon, P. O., Engesser, B., Berger, J. P., Bucher, H., \& Weidmann, M. (1985). Sur l'âge de la Molasse d'eau douce inférieure de Boudry, Neuchâtel. Eclogae Geologicae Helvetiae, 78, 631-667.

Muir-Wood, R., \& King, G. C. P. (1993). Hydrological signatures of earthquake strain. Journal of Geophysical Research, 98, 22035-22068.

Müller, H., \& Leupin, O. (2012). WS-H (Investigation of wet spots): Observation, first experimental results, and a short presentation of possible hypotheses regarding the origin of these waters. Mont Terri Technical Note, TN 2012-96, 49 pp. Federal Office of Topography (swisstopo), Wabern. www.mont-terri.ch.

Nussbaum, C., Bossart, P., Amann, F., \& Aubourg, C. (2011). Analysis of tectonic structures and excavation induced fractures in the Opalinus Clay, Mont Terri underground rock laboratory (Switzerland). Swiss Journal of Geosciences, 104, 187-210.

Nussbaum, C., Kloppenburg, A., Caër, T., \& Bossart, P. (2017). Tectonic evolution around the Mont Terri rock laboratory, northwestern Swiss Jura: Constraints from kinematic forward modelling. Swiss Journal of Geosciences, 110 (this issue).

Nussbaum, C., Meier, O., Masset, O., \& Badertscher, N. (2006). Selfsealing of fault (SF) Experiment-Drilling of resin impregnated boreholes. Mont Terri Technical Note, TN 2006-22, 36 pp. Federal Office of Topography (swisstopo), Wabern. www.montterri.ch.

O’Neil, J. R., Clayton, R. N., \& Mayeda, T. K. (1969). Oxygen isotope fractionation in divalent metal carbonates. Journal of Chemistry and Physics, 51, 5547-5558.

Parkhurst, D. L., \& Appelo, C. A. J. (2013). Description of input and examples for PHREEQC version 3-A computer program for speciation, batch-reaction, one-dimensional transport, and inverse geochemical calculations. U.S. Geological Survey Techniques and Methods, Book 6, 497. http://pubs.usgs.gov/tm/06/ a43.

Pearson, F. J., Arcos, D., Bath, A., Boisson, J. Y., Fernandez, A. M., Gäbler, H. E., et al. (2003). Mont Terri project-Geochemistry of water in the Opalinus Clay formation at the Mont Terri Rock Laboratory (319 pp.). Reports of the Federal Office for Water and Geology, Geology Series, No. 5. Federal Office of Topography (swisstopo), Wabern. www.mont-terri.ch.

Pearson, F. J., Balderer, W., Loosli, H. H., Lehmann, B. E., Matter, A., Peters, T., et al. (1991). Applied Isotope Hydrogeology-A case study in northern Switzerland. Amsterdam: Elsevier.

Pfirter, U., Antenen, M., Heckendorn, W., Burkhalter, R. M., Gürler, B., \& Krebs, D. (1996). Geologischer Atlas der Schweiz.
1:25'000, Blatt Moutier. Federal Office of Topography (swisstopo), Wabern. www.map.geo.admin.ch.

Philippot, A. C., Michelot, J. L., \& Marlin, C. (2000). A paleohydrogeological study of the Mol site, Belgium (PHYMOL project). Rapport spécifique no. 3: Analyse des isotope et des gaz nobles. European Commission Report, DOC RTD/55/2000-FR.

Picot, L., Becker, D., Cavin, L., Pirkenseer, C., Lapaire, F., Rauber, G., et al. (2008). Sédimentologie et paléontologie des paléoenvironnements côtiers rupéliens de la Molasse marine rhénane dans le Jura suisse. Swiss Journal of Geosciences, 101, 483-513.

Pierre, C. (1989). Sedimentation and diagenesis in restricted marine basins. In P. Fritz \& J. C. Fontes (Eds.), Handbook of environmental isotope geochemistry (Vol. 3A, pp. 257-315). Burlington: Elsevier.

Pirkenseer, C., Berger, J. P., \& Reichenbacher, B. (2013). The position of the Rupelian/Chattian boundary in the southern Upper Rhine Graben based on new records of microfossils. Swiss Journal of Geosciences, 106, 291-301.

Pirkenseer, C., Spezzaferi, S., \& Berger, J. P. (2010). Palaeoecology and biostratigraphy of the Paleogene Foraminifera from the southern Upper Rhine Graben and the influence of reworked planktonic Foraminifera. Palaeontographica, Abteilung A: Palaeozoology-Stratigraphy, 293, 1-93.

Pirkenseer, C., Spezzaferi, S., \& Berger, J. P. (2011). Reworked microfossils as a paleogeographic tool. Geology, 39, 843-846.

Raiswell, R., \& Canfield, D. E. (2012). The iron biogeochemical cycle past and present. Geochemical Perspectives, 1, 1-220.

Rübel, A. P., Sonntag, C., Lippmann, J., Pearson, F. J., \& Gautschi, A. (2002). Solute transport in formations of very low permeability: Profiles of stable isotope and dissolved noble gas contents of pore water in the Opalinus Clay, Mont Terri, Switzerland. Geochimica et Cosmochimica Acta, 66, 1311-1321.

Stute, M., \& Schlosser, P. (2000). Atmospheric noble gases. In P. G. Cook \& A. L. Herczeg (Eds.), Environmental tracers in subsurface hydrology (pp. 349-377). Boston: Kluwer.

Thury, M., \& Bossart, P. (1999). The Mont Terri rock laboratory, a new international research project in a Mesozoic shale formation, in Switzerland. Engineering Geology, 52, 347-359.

Van Loon, L. R., Baeyens, B., \& Bradbury, M. H. (2005a). Diffusion and retention of sodium and strontium in Opalinus clay: Comparison of sorption data from diffusion and batch sorption measurements, and geochemical calculations. Applied Geochemistry, 20, 2351-2363.

Van Loon, L. R., Müller, W., \& Iijima, K. (2005b). Activation energies of the self-diffusion of HTO, ${ }^{22} \mathrm{Na}^{+}$and ${ }^{36} \mathrm{Cl}^{-}$in a highly compacted argillaceous rock (Opalinus Clay). Applied Geochemistry, 20, 961-972.

Van Loon, L. R., \& Soler, J. M. (2003). Diffusion of HTO, ${ }^{36} \mathrm{Cl}^{-}$, ${ }^{125} \mathrm{I}^{-}$and ${ }^{22} \mathrm{Na}^{+}$in Opalinus Clay: Effect of confining pressure, sample orientation, sample depth and temperature. Nagra Technical Report, 03-07, 119 pp. Nagra, Wettingen. www. nagra.ch.

Vinsot, A., Appelo, C. A. J., Cailteau, C., Wechner, S., Pironon, J., De Donato, P., et al. (2008). $\mathrm{CO}_{2}$ data on gas and pore water sampled in situ in the Opalinus Clay at the Mont Terri rock laboratory. Physics and Chemistry of the Earth, 33, S54-S60.

Vinsot, A., Appelo, C. A. J., Lundy, M., Wechner, S., Lettry, Y., Lerouge, C., et al. (2014). In situ diffusion test of hydrogen gas in the Opalinus Clay. Geological Society, London, Special Publications, 400(1), 563-578.

Vogt, T. (2013). WS-I Experiment-Outflow measurements and hydrochemical analyses. Mont Terri Technical Note, TN 2013-01, 10 pp. Federal Office of Topography (swisstopo), Wabern. www.mont-terri.ch.

Wang, C. Y., \& Manga, M. (2010). Earthquakes and water (225 pp). Berlin Heidelberg: Springer. 
Weidmann, M., Engesser, B., Berger, J. P., Mojon, P. O., Ginsburg, L., Becker, D., et al. (2014). Paléontologie et biostratigraphie de la Molasse de l'Oligocène et du Miocène basal du Talent et d'autres localités du Plateau vaudois (Suisse). Revue de Paléobiologie (Genève), 33, 463-531.

Wersin, P., Leupin, O. X., Mettler, S., Gaucher, E. C., Mäder, U., De Cannière, P., et al. (2011). Biogeochemical processes in a clay formation in situ experiment: Part A-Overview, experimental design and water data of an experiment in the Opalinus Clay at the Mont Terri Underground Research Laboratory, Switzerland. Applied Geochemistry, 26, 931-953.

Zachos, J. C., Dickens, G. R., \& Zeebe, R. E. (2008). An early Cenozoic perspective on greenhouse warming and carbon-cycle dynamics. Nature, 451, 279-283. 